DOE/FETC-98/1071

(DE98002060)

\title{
A Partial Oxidation Technique for Fuel-Cell Anode Exhaust-Gas Synthesis
}

\author{
Randall S. Gemmen \\ Edward H. Robey, Jr.
}

October 1998

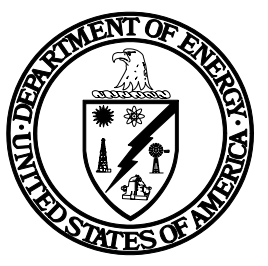

U.S. Department of Energy Federal Energy Technology Center Pittsburgh, Pennsylvania

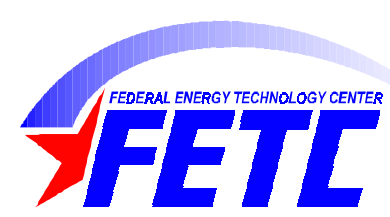

Morgantown, West Virginia 


\section{Disclaimer}

This report was prepared as an account of work sponsored by an agency of the United States Government. Neither the United States Government nor any agency thereof, nor any of their employees, makes any warranty, express or implied, or assumes any legal liability or responsibility for the accuracy, completeness, or usefulness of any information, apparatus, product, or process disclosed, or represents that its use would not infringe privately owned rights. Reference herein to any specific commercial product, process, or service by trade name, trademark, manufacturer, or otherwise does not necessarily constitute or imply its endorsement, recommendation, or favoring by the United States Government or any agency thereof. The views and opinions of authors expressed herein do not necessarily state or reflect those of the United States Government or any agency thereof.

Available to DOE employees and contractors from the Office of Scientific and Technical Information, P.O. Box 62, 175 Oak Ridge Turnpike, Oak Ridge, TN 37831; prices are available by phone: (423) 576-8401; fax: (423) 576-5725; or e-mail: reports@adonis.osti.gov.

Available to the public from the National Technical Information Service, U.S. Department of Commerce, 5285 Port Royal Road, Springfield, VA 22161; phone orders accepted at (703) 487-4650. 


\section{Abstract}

This paper describes the performance of a gas generator used to synthesize the exhaust gas from the anode of a molten-carbonate fuel cell. The composition of this gas is estimated to be that of equilibrium at $1,250{ }^{\circ} \mathrm{F}$ and $1 \mathrm{~atm}: 48 \% \mathrm{CO}_{2}, 39 \% \mathrm{H}_{2} \mathrm{O}, 5 \% \mathrm{CO}$, and $8 \% \mathrm{H}_{2}$, with an energy content of approximately $39 \mathrm{Btu} / \mathrm{scf}$ (higher heating value). To synthesize a range of gas compositions around this point, the gas generator partially oxidizes a mixture of $\mathrm{CH}_{4}, \mathrm{O}_{2}$, and $\mathrm{CO}_{2}$ to generate energy densities between 20 and $60 \mathrm{Btu} / \mathrm{scf}$ at temperatures between 1,198 and $1,350{ }^{\circ} \mathrm{F}$. Results show that the technique provides a relatively high ratio of $\mathrm{CO}$ to $\mathrm{H}_{2}$ concentrations compared with the target composition $\left(\mathrm{CO}: \mathrm{H}_{2}\right.$ of 2, versus 0.71$)$. A detailed chemical model shows that the likely cause is quenching of the $\mathrm{CO}$ and $\mathrm{H}_{2}$ chemistry below $2,000{ }^{\circ} \mathrm{F}$. 


\section{Acknowledgment}

The authors would like to express their thanks to Rick Addis for his support and technical expertise in constructing and running the gas generator. 


\section{Contents}

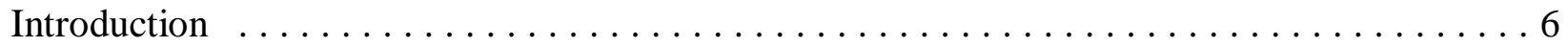

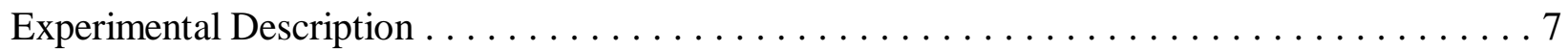

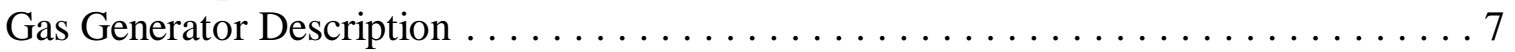

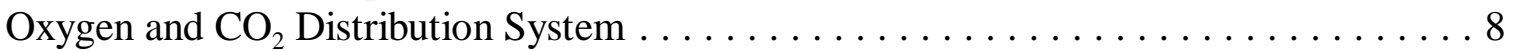

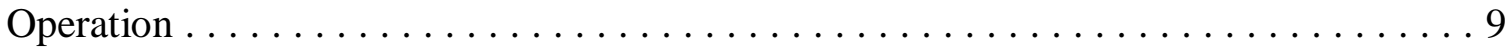

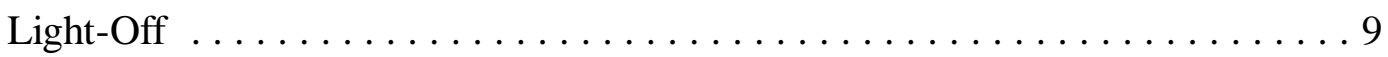

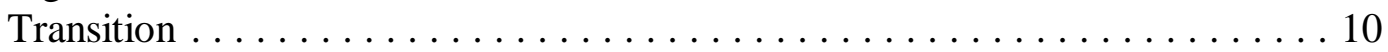

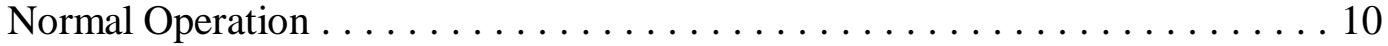

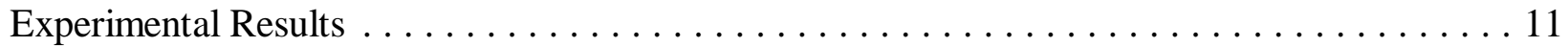

Model ..................................... 13

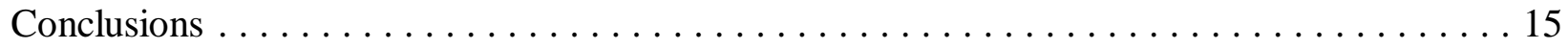

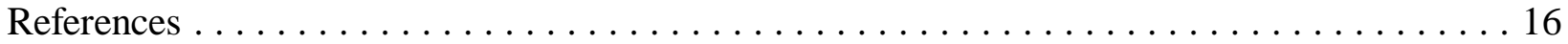

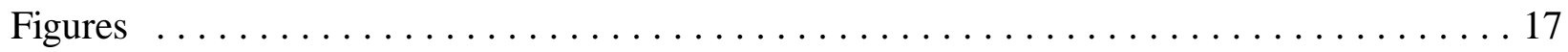

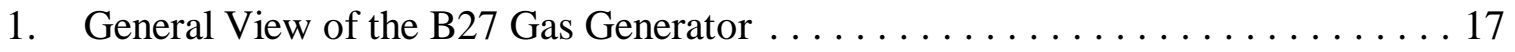

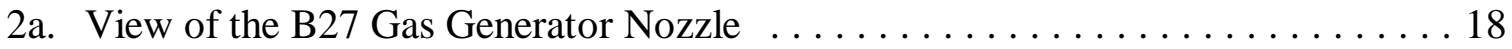

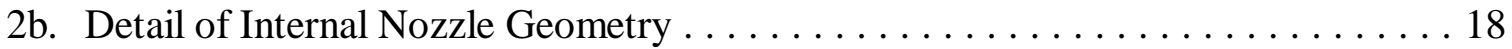

3. Gas Generator Pilot Tube and Swirl Vane . . . . . . . . . . . . . . . . . . . 19

4. Schematic of Gas Generator . . . . . . . . . . . . . . . . . . . . . . . 19

5. Schematic of Gas Generator Oxygen and Carbon Dioxide Supplies . . . . . . . . . 20

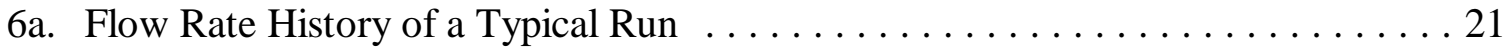

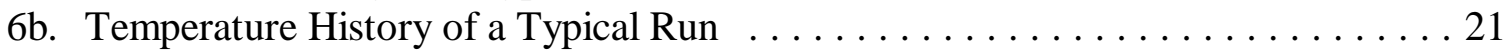

7. Product Gas Composition Versus Fuel-to-Oxygen Ratio . . . . . . . . . . . . . 22

8. Ternary Plot of Product Gas Compositions (Volume Basis, Dry) . . . . . . . . . 23

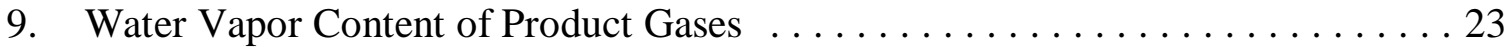

10. Energy Content (Wet Basis) of Product Gases $\ldots \ldots \ldots \ldots \ldots \ldots \ldots \ldots \ldots \ldots$

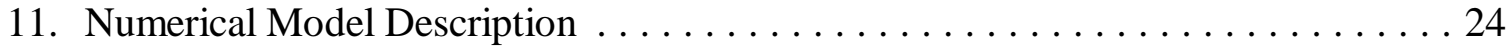

12. Model Results Showing Quenching of $\mathrm{CO}$ and $\mathrm{H}_{2}$ Inside the Gas Generator . . . . 25

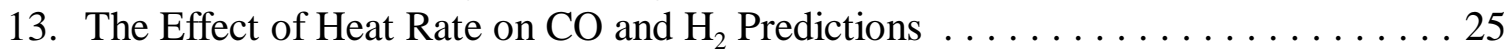

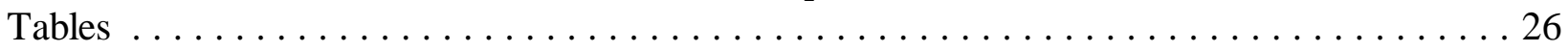

1. Initial Valve Settings for the Gas Generator Nozzle $\ldots \ldots \ldots \ldots \ldots \ldots \ldots$

2. Transition Steps from Start-Up to Normal Gas Generator Operation . . . . . . . . . 27

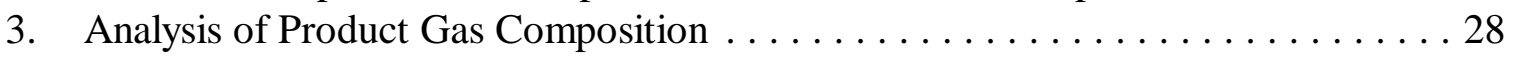

Appendix . . . . . . . . . . . . . . . . 30 


\section{Introduction}

There are a variety of methods for producing a synthesis gas (syngas) of desired composition, temperature, and pressure, e.g., autothermal converters, catalytic/steam reforming, and partial oxidation techniques. This paper presents a gas generator system used to produce a syngas to simulate the energy densities found in the off-gas from the anode of a molten-carbonate fuel cell. These fuel cells operate at about $1,250{ }^{\circ} \mathrm{F}$, with anode off-gas energy densities of about 40 to $50 \mathrm{Btu} / \mathrm{scf}$ (Carlson 1997). The composition of this gas is estimated to be that of equilibrium: $48 \% \mathrm{CO}_{2}, 39 \% \mathrm{H}_{2} \mathrm{O}, 5 \% \mathrm{CO}$, and $8 \% \mathrm{H}_{2}$, with an energy content of approximately $39 \mathrm{Btu} / \mathrm{scf}$ (higher heating value). The partial oxidation technique was selected for this gas generator system. This system provided a range of fuel energy densities with nearly fixed $\mathrm{H}_{2}: \mathrm{CO}$ ratios at temperatures between 1,198 and $1,350{ }^{\circ} \mathrm{F}$. To further understand the performance of

this system, a detailed kinetics model of the system was executed and its results were compared to the experimental data. 


\section{Experimental Description}

\section{Gas Generator Description}

A gas generator is used to create a low heating value gas, consisting of water vapor, $\mathrm{CO}_{2}$, $\mathrm{CO}$, and $\mathrm{H}_{2}$, through the incomplete combustion of natural gas in an atmosphere of $\mathrm{O}_{2}$ and $\mathrm{CO}_{2}$. Liquid $\mathrm{O}_{2}$ and liquid $\mathrm{CO}_{2}$ Dewars supply $\mathrm{O}_{2}$ and $\mathrm{CO}_{2}$ gas at baseline flow rates of $386 \mathrm{scf} / \mathrm{h}$ (182 slpm) and $289 \mathrm{scf} / \mathrm{h}(136 \mathrm{slpm})$, respectively. These gases are mixed with natural gas at a baseline flow of $225 \mathrm{scf} / \mathrm{h}$ (106 slpm) in a nozzle, and are burned inside a water-cooled combustor. A general view of the gas generator is shown in Figure 1. The gas generator combustor is composed of a carbon steel vessel lined with approximately 1 inch $(25.4 \mathrm{~mm})$ of Plicast 40 refractory (i.d. 10.6 inches $(0.27 \mathrm{~m})$ ) and wrapped outside with copper cooling coils. The axial dimension inside the combustor is approximately 34 inches $(0.864 \mathrm{~m})$. The vessel is suspended from above by a steel framework. Gas supplies enter the gas generator through the nozzle on top, react inside the vessel, and exit the reactor through a 2 inch $(51 \mathrm{~mm})$ port on the bottom left. A sight glass on the bottom flange of the vessel provides optical access. In a typical application, a video camera is focused through the sight glass to transmit an image of the flame to the control room. A flame detector and a thermocouple are tied to a safety interlock system to automatically shut off the fuel and $\mathrm{O}_{2}$ if the flame goes out.

A general view of the nozzle arrangement is shown in Figure 2a, and a detailed view of the nozzle internal geometry is shown in Figure 2b. The body of the nozzle is composed of a section of 1-inch schedule-40 carbon steel pipe. A length of 1/2-inch $(13 \mathrm{~mm})$ diameter stainless steel tubing is located in the center of the pipe to act as a concentric pilot. A 1/4-inch $(6.35 \mathrm{~mm})$ ceramic tube containing a 1/16-inch $(1.59 \mathrm{~mm})$ stainless steel electrode enters the pilot tube through a cross fitting on the top, and extends down the center to within 1.25 inches $(32 \mathrm{~mm})$ of the end of the nozzle. Fuel (natural gas) is delivered through a tube shown on the left side of the figure and branches into two paths, one leading to the cross on the top of the pilot tube and the other leading to the main annulus fitting on the top left of the 1-inch pipe. The relative flow split between pilot fuel and main fuel is controlled by adjusting flow control valves (FCVs) 30 and 31, respectively. The combustion air for the nozzle also enters on the left side (Figure 2), and splits into main and pilot streams, which are controlled by FCVs 32 and 33, respectively. These lines pass around the rear of the nozzle and meet their respective $\mathrm{O}_{2} / \mathrm{CO}_{2}$ mixture streams before entering the pilot tube and main annulus. $\mathrm{O}_{2}$ and $\mathrm{CO}_{2}$ supplies enter from the right side (Figure 2), mix, and split into main annulus and pilot streams. The relative flow splits of main and pilot $\mathrm{O}_{2} / \mathrm{CO}_{2}$ mixtures are controlled by setting FCVs 32 through 35. As previously indicated, these flows meet and mix with the main and pilot air streams prior to entering the nozzle.

The main air $/ \mathrm{O}_{2} / \mathrm{CO}_{2}$ mixture mixes with the main fuel stream as it passes down the annulus defined by the 1-inch outer pipe and the 1/2-inch pilot tube. The main flow is further mixed and made uniform when it passes through a 1-inch $(25.4 \mathrm{~mm})$ section of densely packed steel window-screen approximately 6.5 inches $(0.165 \mathrm{~m})$ from the downstream end of the nozzle. It is then swirled by passing over five 45-degree flat swirl vanes (Figure 3). In order to reduce the likelihood of a flashback in the nozzle, the main flow is accelerated by a reduction of cross- 
sectional area created by attaching a 0.745 -inch $(19 \mathrm{~mm})$ o.d. sleeve to the pilot tube and inserting a sleeve in the 1-inch pipe to reduce its inside diameter to 0.950 inch $(24 \mathrm{~mm})$. The steel sleeve added to the pilot tube also has five swirl vanes to maintain the swirling flow. Gas velocity in the annulus between the sleeves is approximately $91 \mathrm{ft} / \mathrm{s}(28 \mathrm{~m} / \mathrm{s})$ at baseline flows. A thermocouple is inserted into the annulus above the upper swirl vanes and is tied into an alarm to warn operators of flashback events. The tip of the steel pilot sleeve originally tapered toward the end of the pilot tube, but after some initial trial and error, it was replaced with a 0.725 -inch diameter $(18 \mathrm{~mm})$, 1.694-inch (43 mm) long ceramic TIG torch cup to make it more durable. The ceramic tip can become quite hot (frequently glowing white-hot) and over a year of operation has sustained some damage, which can be seen in the figure.

Some of the other pertinent features of the gas generator are shown in Figure 4. In addition to the air, fuel, $\mathrm{O}_{2}$, and $\mathrm{CO}_{2}$ supplies entering through the nozzle, other inputs include purge air (to reduce condensation on the sight glass), and cooling water. The purge air mixes/reacts with the product gases, and must be turned off when synthesizing the anode gas. The cooling water does not mix with the reactants. Its purpose is to limit the shell temperature of the gas generator and, to a degree, control the temperature of the product gases. Four separate cooling zones exist inside and outside the vessel. A portion of a cooling coil wrapped around the bottom of the nozzle can be seen in Figure 2. Two type-R thermocouples are used to monitor the temperature of the process: (1) TE-012 is used to monitor the flame and is tied to the safety interlock system, and (2) TE-927 is used to measure the temperature of the product gases leaving the gas generator. Not shown are three thermocouples used to monitor the vessel wall temperature. A slip stream of the product gas is withdrawn approximately $10 \mathrm{ft}(3.05 \mathrm{~m})$ downstream of the gas generator for analysis. The bulk of the gas passes on to a $10 \mathrm{ft}$-long $(3.05 \mathrm{~m})$ development combustor used to investigate oxidation strategies for the low Btu gas mixture. The gas then mixes with dilution air, after which it passes out a $20 \mathrm{ft}(6.1 \mathrm{~m})$ stack.

\section{Oxygen and $\mathrm{CO}_{2}$ Distribution System}

Because of the unique requirements of using pure oxygen in combustion systems, the general facilities used in this project will be described, with particular attention given to the oxygen and carbon dioxide systems.

Feedstocks for the gas generator include combustion air (for start-up only), natural gas, $\mathrm{O}_{2}$, and $\mathrm{CO}_{2}$. The air and natural gas are taken from FETC's standard facilities (the 700 psia $(4.8 \mathrm{MPa})$ air system and the $50 \mathrm{psia}(0.34 \mathrm{MPa})$ natural gas system). $\mathrm{O}_{2}$ and $\mathrm{CO}_{2}$ are supplied from Dewars of liquid $\mathrm{O}_{2}$ and liquid $\mathrm{CO}_{2}$ stored in a shed located near the project area. Two Dewars of each gas provide sufficient supplies for a week at our normal test schedule (i.e., about three 8-hour days of operation per week). As shown in Figure 5, the $\mathrm{CO}_{2}$ Dewars are manifolded together. This manifold draws gas from the Dewar with the highest pressure, and includes a regulator for the supply pressure. Gaseous $\mathrm{CO}_{2}$ is provided from the manifold at a pressure of approximately $100 \mathrm{psig}(0.69 \mathrm{MPa})$. The temperature of this gas can be quite low (e.g., $-50{ }^{\circ} \mathrm{F}$ $\left.\left(-45^{\circ} \mathrm{C}\right)\right)$, but it is heated to approximately $80^{\circ} \mathrm{F}\left(27^{\circ} \mathrm{C}\right)$ by a heater constructed of six passes (i.e., three loops) of flow tubing bundled together with four 6-ft resistance heating elements (500 W each). 
The $\mathrm{O}_{2}$ system is similar to the $\mathrm{CO}_{2}$ system except that (1) it is constructed of rigid copper tubing and brass fittings, (2) all parts were specially designed and cleaned for $\mathrm{O}_{2}$ service, (3) the manifold includes a heat exchanger to help vaporize the $\mathrm{O}_{2}$, and (4) both the gas and the liquid ports of the Dewars are used in order to provide enough flow. A heater is provided to warm the oxygen, but it is rarely needed.

\section{Operation}

\section{Light-Off}

The gas generator is lit-off with air and natural gas and is operated for a period of time to warm it and any downstream applications prior to making the transition to $\mathrm{O}_{2} / \mathrm{CO}_{2} /$ fuel operation. The light-off process is easily accomplished if the flow split between the pilot and main gas mixtures is properly set. The flow splits are controlled by the settings of FCVs 30 through 35 . Initial settings for these valves are shown in Table 1. Any deviation from these settings, or any alteration of the nozzle that would alter the pilot/main flow splits, can make the gas generator difficult to light.

This section provides an overview of the light-off procedure. On many burners, the pilot flame is lit first and then the main fuel is brought on gradually until the main flame is established. The main air, pilot air, and fuel supplies for the gas generator are not metered and controlled separately, thereby requiring a different light-off strategy. To light the gas generator, the air flows are established, the spark is turned on, and then fuel is suddenly provided to the pilot and main streams, igniting both nearly simultaneously. The general procedure is as follows:

- $\quad$ Establish dilution air flow to the stack $(10,000 \mathrm{scf} / \mathrm{h}(4700 \mathrm{slpm}))$.

- $\quad$ Establish combustion air flow (800 scf/h (377 slpm)).

- $\quad$ Engage the keyed shut-off (to enable the fuel solenoid and ignitor power).

- $\quad$ Set the fuel-flow controller in manual mode at a valve position setting that will provide $75 \mathrm{scf} / \mathrm{h}(35 \mathrm{slpm})$ natural gas when the fuel shut-off solenoid is opened.

- Turn on the ignitor toggle switch. Verify via the video monitor.

- $\quad$ Enable the fuel toggle switch.

- $\quad$ Depress and hold the start-up override button. This will open the fuel solenoid until the flame is established and the flame detector (peeper) and temperature interlocks are satisfied. The flame should ignite within several seconds of depressing the override button.

- $\quad$ Verify the presence of the flame visually on the video monitor and on the data acquisition computer by observing TE-012.

- $\quad$ Start the flame detector (peeper).

- When the temperature at TE-012 is well above $1,000{ }^{\circ} \mathrm{F}\left(537^{\circ} \mathrm{C}\right)$, the override button may be released and the spark toggle switched off.

The gas generator can be left at these flows for an initial warm-up period, or the air and fuel may be increased in stages to $1,000 \mathrm{scf} / \mathrm{h}(471 \mathrm{slpm})$ air and $95 \mathrm{scf} / \mathrm{h}$ (45 slpm) fuel to 
provide a more rapid warm-up. At air flows greater that $1,000 \mathrm{scf} / \mathrm{h}$, the gas generator becomes somewhat unstable and is more likely to blow out.

Plots showing the gas flow rates and selected temperatures during the phases of light-off, transition, and normal operation of a "typical" run are shown in Figures $6 \mathrm{a}$ and $6 \mathrm{~b}$. The combustor was lit just after 8:15, after which the air and fuel flows were increased to 1,000 scf/h and $90 \mathrm{scf} / \mathrm{h}$, respectively, for about $1 / 2$ hour before beginning the transition to baseline conditions, which began at 9:30.

\section{Transition}

Through engineering judgement and trial and error, a procedure was developed to transition the gas generator from its light-off conditions on air and fuel to operation on $\mathrm{O}_{2}, \mathrm{CO}_{2}$, and fuel at "baseline" operating conditions. During the initial stages of the transition, the gas generator flame is sensitive to operating conditions, and is likely to blow out if conditions deviate much outside the plan. During the latter stages of transition, when the gas generator is consuming substantial quantities of oxygen, the flame is more stable. The steps for the transition are summarized in Table 2. Note that at step \#31, the gas generator is consuming $386 \mathrm{scf} / \mathrm{h}$ (182 slpm) $\mathrm{O}_{2}, 289 \mathrm{scf} / \mathrm{h}(136 \mathrm{slpm}) \mathrm{CO}_{2}, 225 \mathrm{scf} / \mathrm{h}(106 \mathrm{slpm})$ natural gas, and $400 \mathrm{scf} / \mathrm{h}$ (189 slpm) air, plus the air from the sight-glass purge. The gas generator is usually left at this step for an hour or more to complete warm-up and to heat downstream experimental hardware. In the example run shown in Figures $6 a$ and 6b, this warm-up interval extended from 9:45 to 11:10. When the systems have reached the desired temperatures, the sight-glass purge may be turned off and the $400 \mathrm{scf} / \mathrm{h}$ air removed from the gas generator. The gas generator will then be running rich, and production of low-Btu fuel will begin. Note that the temperature of the product gases will begin to fall after completing the transition (e.g., note the drop in product gas temperature at just before 11:15 in Figure 6b). Heat energy that was being released inside the gas generator prior to completion of the transition now leaves the gas generator in the form of chemical energy (unburned $\mathrm{CO}$ and $\mathrm{H}_{2}$ ).

\section{Normal Operation}

After completing the transition to normal operation, the gas generator flame remains stable. For example, it will operate with fuel flow rates as low as $100 \mathrm{scf} / \mathrm{h}$ (47 slpm) without flaming out. This flexibility provides a means of varying the heating value of the product gas over a range of 0 to $70 \mathrm{Btu} / \mathrm{scf}\left(2.6 \mathrm{MJ} / \mathrm{m}^{3}\right)$.

Temperatures measured about 6 inches $(0.152 \mathrm{~m})$ downstream of the flame are generally 2,200 to $2,300{ }^{\circ} \mathrm{F}\left(1,200\right.$ to $\left.1,260{ }^{\circ} \mathrm{C}\right)$ (not corrected for radiation effects), while product gas temperatures are typically $1,500{ }^{\circ} \mathrm{F}\left(815^{\circ} \mathrm{C}\right)$. In Figure $6 \mathrm{~b}$, the product gas temperature excursions above $1,500{ }^{\circ} \mathrm{F}\left(815^{\circ} \mathrm{C}\right)$, occurring at 12:00 and 13:00, were caused by turning the sight-glass purge air on to provide excess oxygen to complete the oxidation, and thereby provide more heat to warm the downstream reactor. Gas generator shell temperatures are typically maintained at about 600 to $700{ }^{\circ} \mathrm{F}\left(316\right.$ to $\left.371{ }^{\circ} \mathrm{C}\right)$, with cooling water venting as steam at approximately $217^{\circ} \mathrm{F}\left(103{ }^{\circ} \mathrm{C}\right)$. 


\section{Experimental Results}

The normalized dry-basis compositions of each sample of gas generator product gas are listed in Table 3. Neither $\mathrm{O}_{2}$ nor $\mathrm{CH}_{4}$ were detected in any significant amount for any of the samples analyzed. A few of these samples were collected while intentionally varying the $\mathrm{O}_{2}, \mathrm{CO}_{2}$, and fuel feedstocks in order to observe the effect on product gas, but most were collected while varying only the fuel (to vary the heating value of gas being provided to the other experimental rig). As a result, the majority of the data shows the effect of varying the fuel flow rate while the $\mathrm{O}_{2}$ and $\mathrm{CO}_{2}$ flow rates were held essentially constant at their baseline values of 386 and $289 \mathrm{scf} / \mathrm{h}$ (182 and $136 \mathrm{slpm}$ ), respectively. The data points where the $\mathrm{CO}_{2}$ flow was not at baseline include $970513 \# 3$ (baseline $+30 \% \mathrm{CO}_{2}$ ), $970513 \# 2$ (baseline $+20 \% \mathrm{CO}_{2}$ ), 970513 \#1 (baseline $+10 \%$ $\mathrm{CO}_{2}$ ), 970513 \#4 (baseline - 10\% $\mathrm{CO}_{2}$ ), 970513 \#5 (baseline - 20\% $\mathrm{CO}_{2}$ ), and $970423 \# 4$ (baseline $\mathrm{O}_{2}$, low fuel, low $\mathrm{CO}_{2}$ ). Similarly, the data points where the $\mathrm{O}_{2}$ flow rate was not at baseline include $970513 \# 7$ (baseline $+7 \% \mathrm{O}_{2}$ ), $970513 \# 6$ (baseline $+4 \% \mathrm{O}_{2}$ ), 970513 \#8 (baseline - 4\% $\mathrm{O}_{2}$ ), $970513 \# 9$ (baseline -8\% $\mathrm{O}_{2}$ ), and 970423 \#6 (baseline $\mathrm{CO}_{2}$, low fuel, low $\mathrm{O}_{2}$ ). The remaining 41 samples were taken at baseline settings of $\mathrm{O}_{2}$ and $\mathrm{CO}_{2}$ flow with a fuel flow rate varying from 197 to $240 \mathrm{scf} / \mathrm{h}(93$ to $113 \mathrm{slpm})$. Note also that $\mathrm{H}_{2}$ data was not taken for several data points from test 971104 . The $\mathrm{CO}$ and $\mathrm{CO}_{2}$ values for these points, identified by shading in the table, are not normalized.

The trends in product gas composition with respect to the amount of gas generator fuel are shown in Figure 7. The relative amount of gas generator fuel is expressed by the fuel-tooxygen ratio. The data spans a fuel-to-oxygen ratio of 0.52 to 0.64 (corresponding to equivalence ratios of approximately 1.04 to 1.28). The bulk of the data comes from those cases where the gas generator fuel was varied. The other two portions of data with off-baseline values of $\mathrm{O}_{2}$ and $\mathrm{CO}_{2}$ flow (as discussed above) are identified by distinct symbols. Trend lines are drawn through the fuel series data for each species. As the feed to the gas generator was made richer, the relative quantities of $\mathrm{H}_{2}$ and $\mathrm{CO}$ increased, while $\mathrm{CO}_{2}$ decreased. The off-baseline data for $\mathrm{O}_{2}$ and $\mathrm{CO}_{2}$ flow rates do not appear to deviate from their trend lines by more than the natural variation in the measurements.

The relative composition of the three dry-state gaseous species can be represented as a point on a ternary component plot as show in Figure 8. Data points falling near the left corner of this plot represent gas mixtures consisting primarily of $\mathrm{CO}_{2}$, points toward the right corner represent larger proportions of $\mathrm{H}_{2}$, and those near the apex are mostly $\mathrm{CO}$. The gases produced by the gas generator consisted largely of $\mathrm{CO}_{2}$, with increasing amounts of $\mathrm{CO}$ and $\mathrm{H}_{2}$ as the fuelto-oxygen ratio increased. Data points with off-baseline $\mathrm{CO}_{2}$ and $\mathrm{O}_{2}$ flow rates fell essentially on the same trend line. Product gases with $\mathrm{CO}$ as high as $30 \%$ and $\mathrm{H}_{2}$ as high as $10 \%$ were produced. Also included on this figure is a point showing the composition of a "typical" fuel-cell anode exhaust-gas predicted by equilibrium models $\left(\mathrm{H}_{2}: \mathrm{CO}=1.411\right)$. This was our initial target composition for the gas generator product, but none of the variations attempted in feedstock flow rates, cooling-water flow rates, and pilot/main feed-mixture split moved the product gas composition off the trend line toward the target. The product gas had relatively more $\mathrm{CO}$ and less $\mathrm{H}_{2}$ than desired. 
Although we could not match our initial target for gas composition, we could alter the product gas composition to match a target energy density (heating value). Dry-basis heating values can easily be inferred from the data in Figure 8. The heating values of $\mathrm{CO}$ and $\mathrm{H}_{2}$ are similar, averaging approximately $330 \mathrm{Btu} / \mathrm{scf}\left(12 \mathrm{MJ} / \mathrm{m}^{3}\right)$. Thus, the diagonal grid lines parallel to the $\mathrm{CO}-\mathrm{H}_{2}$ boundary line represent approximately equal heating values, ranging from $330 \mathrm{Btu} / \mathrm{scf}$ on the right to $0 \mathrm{Btu} / \mathrm{scf}$ at the lower left corner. The heating value of product gases plotted on this figure vary from 33 to $132 \mathrm{Btu} / \mathrm{scf}\left(1.2\right.$ to $\left.4.9 \mathrm{MJ} / \mathrm{m}^{3}\right)$ on a dry basis.

In order to express the heating value of the product gases on a wet basis, it was necessary to estimate the quantity of water vapor. This was done by using material balance calculations to balance the mass flow rate of oxygen entering (as $\mathrm{O}_{2}$ and $\mathrm{CO}_{2}$ ) and leaving $\left(\right.$ as $\mathrm{CO}_{2}, \mathrm{CO}$, and $\mathrm{H}_{2} \mathrm{O}$ ) the gas generator. A QuickBASIC program was written in which a subroutine calculated the oxygen mass-balance error as a function of the volume fraction of water vapor in the product gas. A bisection routine was then used to solve for the amount of water vapor. The program is attached as an Appendix. The calculations showed that the product gas averaged around $46 \%$ water vapor by volume with a slight decreasing trend as the fuel-to-oxygen ratio was increased. Figure 9 shows these results, along with a least-squares fit line through the data. The wet-basis heating values of the product gases are shown in Figure 10. As the fuel-to-oxygen ratio was increased, the heating value of the product gases increased. In many of our experiments, it was necessary to know the energy content of the gas generator product, but there was insufficient time to take a complete gas sample. For these instances, we relied on the empirical correlation of energy content with the fuel-to-oxygen ratio. This correlation was based on gas sample data from tests 970423 through 970530, and is represented by the dashed line in Figure 10. This equation provided an adequate fit to the original data, as well as subsequent data taken to periodically validate the gas compositions and energy densities. 


\section{Model}

A simplified combustor model employing detailed chemical kinetics was used to analyze and predict the performance of the gas generator system. The main goal of the study was to understand the cause for the high $\mathrm{CO}$ level, relative to equilibrium, over the range of temperatures studied $\left(1,350\right.$ to $1,980{ }^{\circ} \mathrm{F}\left(732\right.$ to $\left.1,082{ }^{\circ} \mathrm{C}\right)$ ). The model considers the detailed evolution of the fuel species inside the partial oxidation combustor, which consists of a series of plug-flow-reactor sections (see Figure 11). Following the usual definitions, for each plug-flow-reactor, the system is considered to be one dimensional and nondiffusive.

For this work, 30 plug-flow-reactor sections were used. The first reactor was supplied with pre-reacted $\mathrm{O}_{2}, \mathrm{CO}_{2}$ and $\mathrm{CH}_{4}$ at the same ratios and total flow used during experimental syngas generation. The temperature of the inlet gas was set at $5,000{ }^{\circ} \mathrm{F}\left(2,760{ }^{\circ} \mathrm{C}\right)$ in order to replicate the thermal energy in the initially reacted gas. This compares well to the adiabatic combustion state and the experimental data, showing that nearly all of the reaction inside this high oxygen environment occurs within the first 2 to 3 inches of the top of the gas generator. As will be seen, these temperatures are high enough to provide quick equilibrium among all species used in the reaction mechanism. Therefore, this modeling technique provides a meaningful way to study the history of each species, and to approximate the chemical processes inside the gas generator as the gases cool and the chemistry becomes "quenched."

To approximate the removal of heat from the system, some quantity of heat is removed at the inlet to each combustor section by dropping the temperature a given amount. The mixture then reacts according to typical plug-flow chemistry until the mixture leaves the combustor section. The simulation uses the reaction set from Kim et al. (1991), which has 12 species, and the thermodynamic data from the Chemkin database (Kee et al. 1989). Because of the parabolic mathematical nature of the proposed model, the solution of the problem is achieved by starting at the first combustor, and then sequentially assessing the solution for each downstream combustor. The solution of each plug-flow-reactor was performed by the LSODE routine described by Radhakrishnan and Hindmarsh (1993). The numerical routines were written in 32-bit C++, and executed on a $233 \mathrm{MHz}$ PC. The model was validated by comparisons with Mulholland et al. (1992), and by direct comparisons with other Chemkin model results for problems representative of the current study.

Figure 12 shows the results of the model in terms of mole fractions for $\mathrm{CO}$ and $\mathrm{H}_{2}$, and the temperature inside the reactor for heat removal rates of about $80^{\circ} \mathrm{F} / \mathrm{inch}\left(1,050{ }^{\circ} \mathrm{C} / \mathrm{m}\right)$, limited by a minimum temperature of $1,250{ }^{\circ} \mathrm{F}\left(676{ }^{\circ} \mathrm{C}\right)$. As already indicated, the species approach equilibrium very quickly at the high temperatures found at the combustor inlet. This is evident in the results; note that following a temperature drop at each plug-flow-reactor inlet, both the $\mathrm{H}_{2}$ and $\mathrm{CO}$ concentrations quickly approach steady state levels, as does the temperature. At these high temperatures, the ratio of $\mathrm{CO}$ to $\mathrm{H}_{2}$ concentrations is nearly $4: 1$. By the time the temperature is about $2,500{ }^{\circ} \mathrm{F}\left(1,371{ }^{\circ} \mathrm{C}\right)$, however, the $\mathrm{CO}$ and $\mathrm{H}_{2}$ chemistry becomes rather slow, and the ratio of $\mathrm{CO}$ to $\mathrm{H}_{2}$ is $3.6: 1$. When the temperature becomes about $1,500{ }^{\circ} \mathrm{F}$ $\left(815^{\circ} \mathrm{C}\right)$, the $\mathrm{CO}$ and $\mathrm{H}_{2}$ chemistry is essentially frozen at a $\mathrm{CO}: \mathrm{H}_{2}$ ratio of $1.8: 1$, which compares well with the experimental data showing $\mathrm{CO}: \mathrm{H}_{2}$ ratios of nearly 2 (Figure 8). 
To investigate the effect of the rate of heat removal from the gas on the model's predictions, similar studies were done at heat removal rates of 103 and $125{ }^{\circ} \mathrm{F} /$ inch $(2,730$ and $2,250{ }^{\circ} \mathrm{C} / \mathrm{m}$ ), with the same limiting lower temperature of $1,250{ }^{\circ} \mathrm{F}$. These results are shown in Figure 13. The figure shows that the rate of heat removal does not change the results significantly. That is, the ratio of $\mathrm{CO}$ to $\mathrm{H}_{2}$ using this partial oxidation technique will always be near $2: 1$. 


\section{Conclusions}

A gas generator was developed to synthesize the gas emitted from the anode of a moltencarbonate fuel cell. The $\mathrm{CO}: \mathrm{H}_{2}$ ratios were found to be much higher than the equilibrium conditions estimated for the anode gas. The model used to investigate this performance showed that the cause was the quenching of the $\mathrm{CO}$ chemistry below $1,500{ }^{\circ} \mathrm{F}$. This resulted in the use of the gas generator for ignition studies of the anode syngas (Gemmen 1998), resulting in a conservative estimate for the ignitability of the true anode syngas. 


\section{References}

Carlson, G. 1997. Energy Research Corporation, Danbury, CT. Personal communication.

Kee, R.J., F.M. Rupley, and J.A. Miller. 1989. Chemkin-II: A Fortran Chemical Kinetics Package for the Analysis of Gas-Phase Chemical Kinetics. Sandia National Laboratory Report, SAND89-8009.

Kim, T.J., R.A. Yetter, and F. L. Dryer. 1994. New Results on Moist CO Oxidation: High Pressure, High Temperature Experiments and Comprehensive Kinetic Modeling. Twenty-Fifth Symposium (International) on Combustion, The Combustion Institute, p. 759-766.

Gemmen, R.S. 1998. Oxidation of Low Calorific Value Gases - Applying Optimization Techniques to Combustor Design. Presented at the 1998 International Joint Power Generation Conference, Baltimore, MD, August 23-26.

Mulholland, J.A., A.F. Sarofim, and J.M. Beer. 1992. On the Derivation of Global Ignition Kinetics from a Detailed Mechanism for Simple Hydrocarbon Oxidation. Combustion Science and Technology 87: 139-156.

Radhakrishnan, K., and A.C. Hindmarsh. 1993. Description and Use of LSODE, the Livermore Solver for Ordinary Differential Equations. NASA Reference Publication 1327. 


\section{Figures}

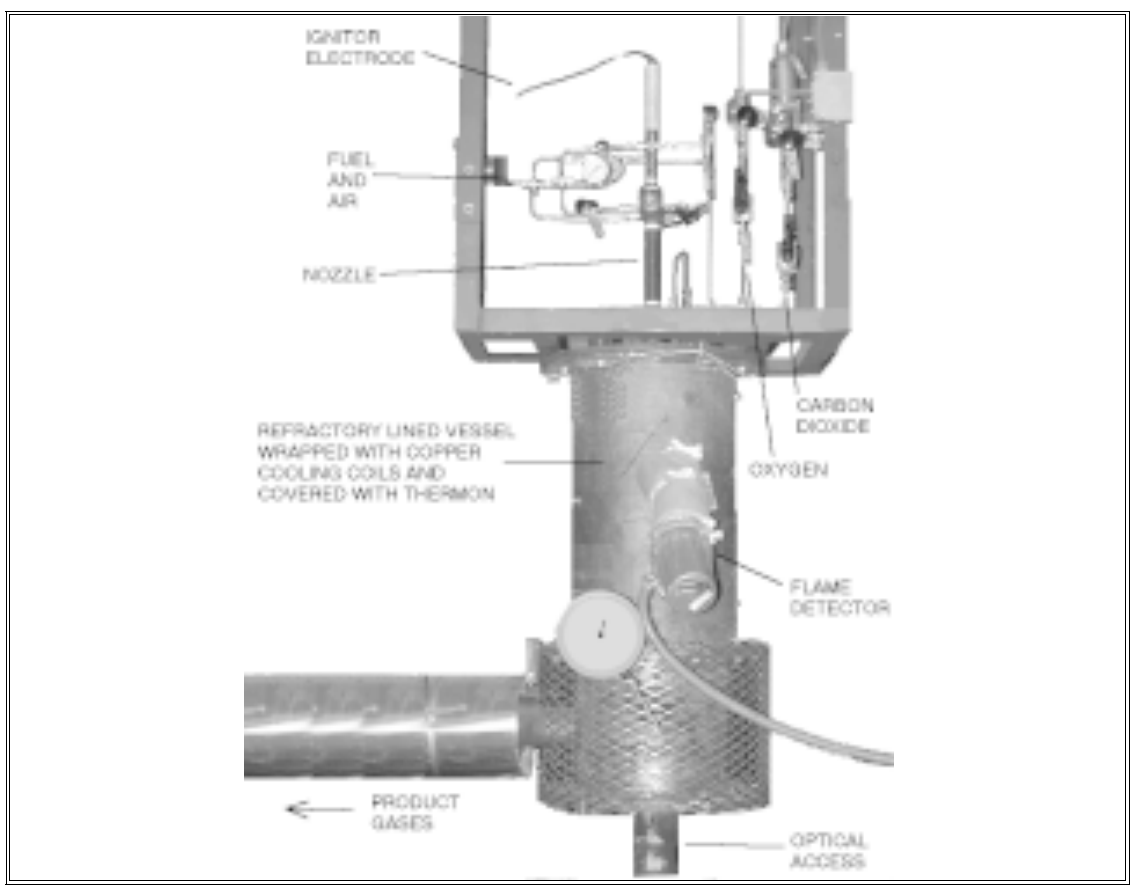

Figure 1. General View of the B27 Gas Generator 


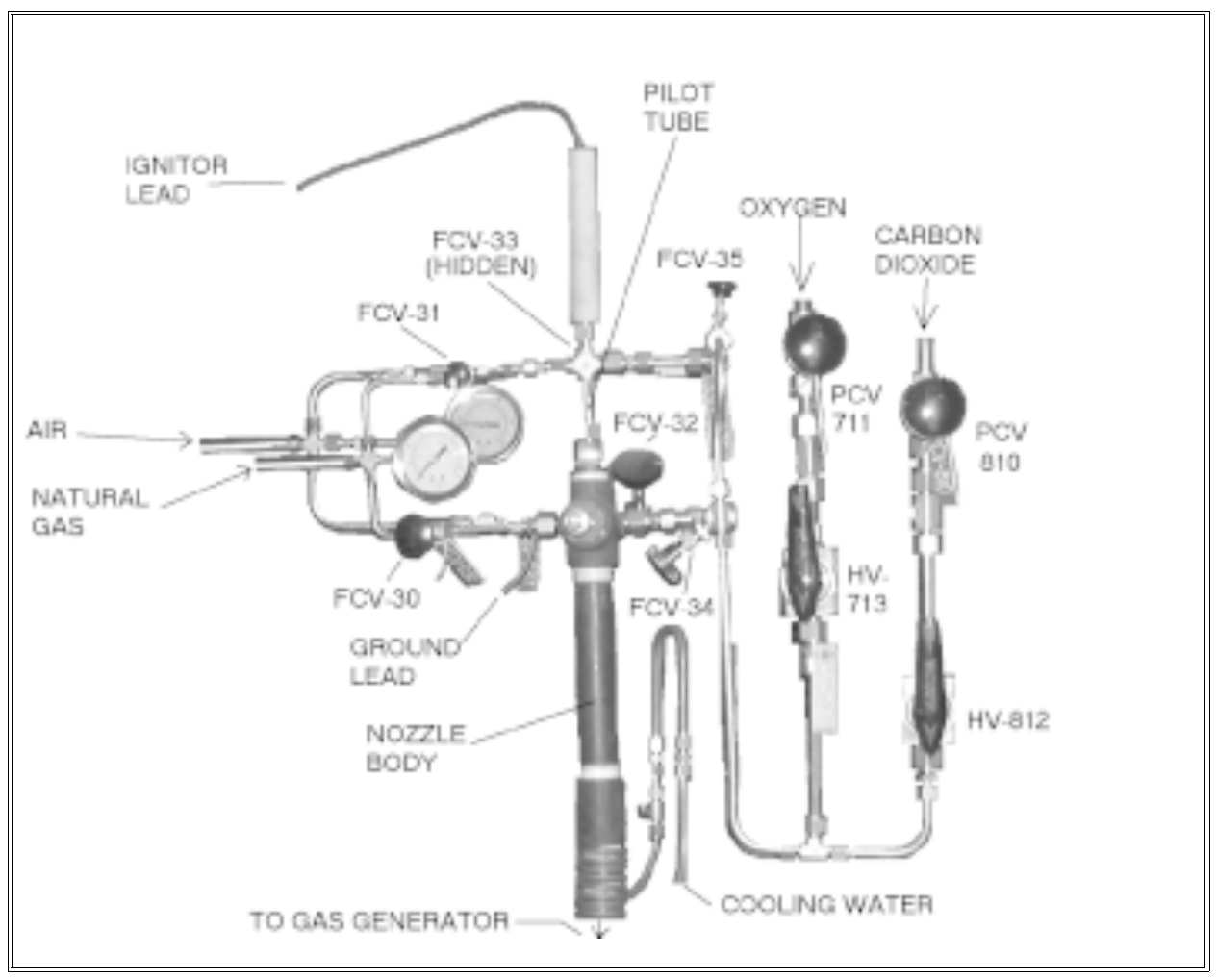

Figure 2a. View of the B27 Gas Generator Nozzle

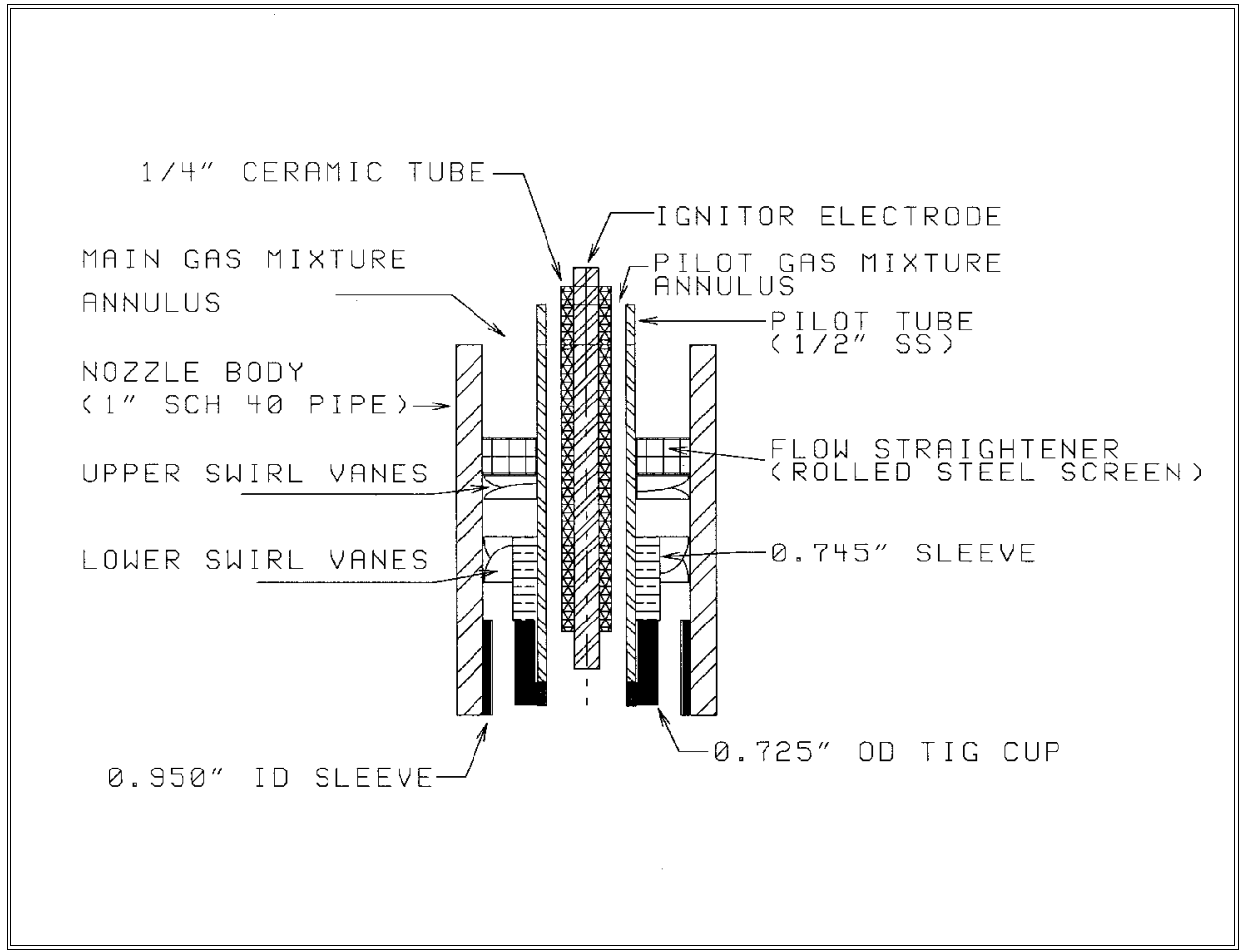

Figure 2b. Detail of Internal Nozzle Geometry ( $x-y$ scales not proportional) 


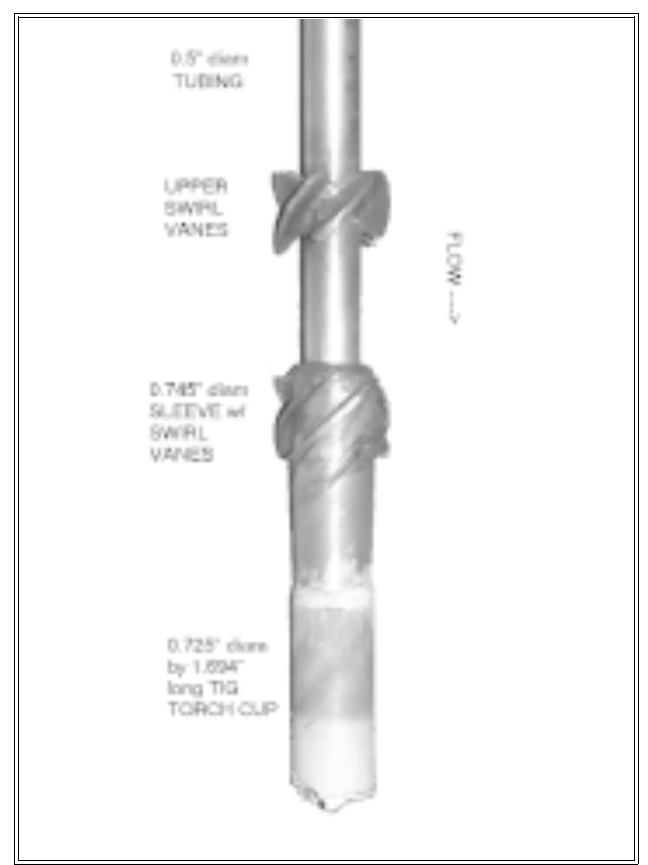

Figure 3. Gas Generator

Pilot Tube and Swirl Vane

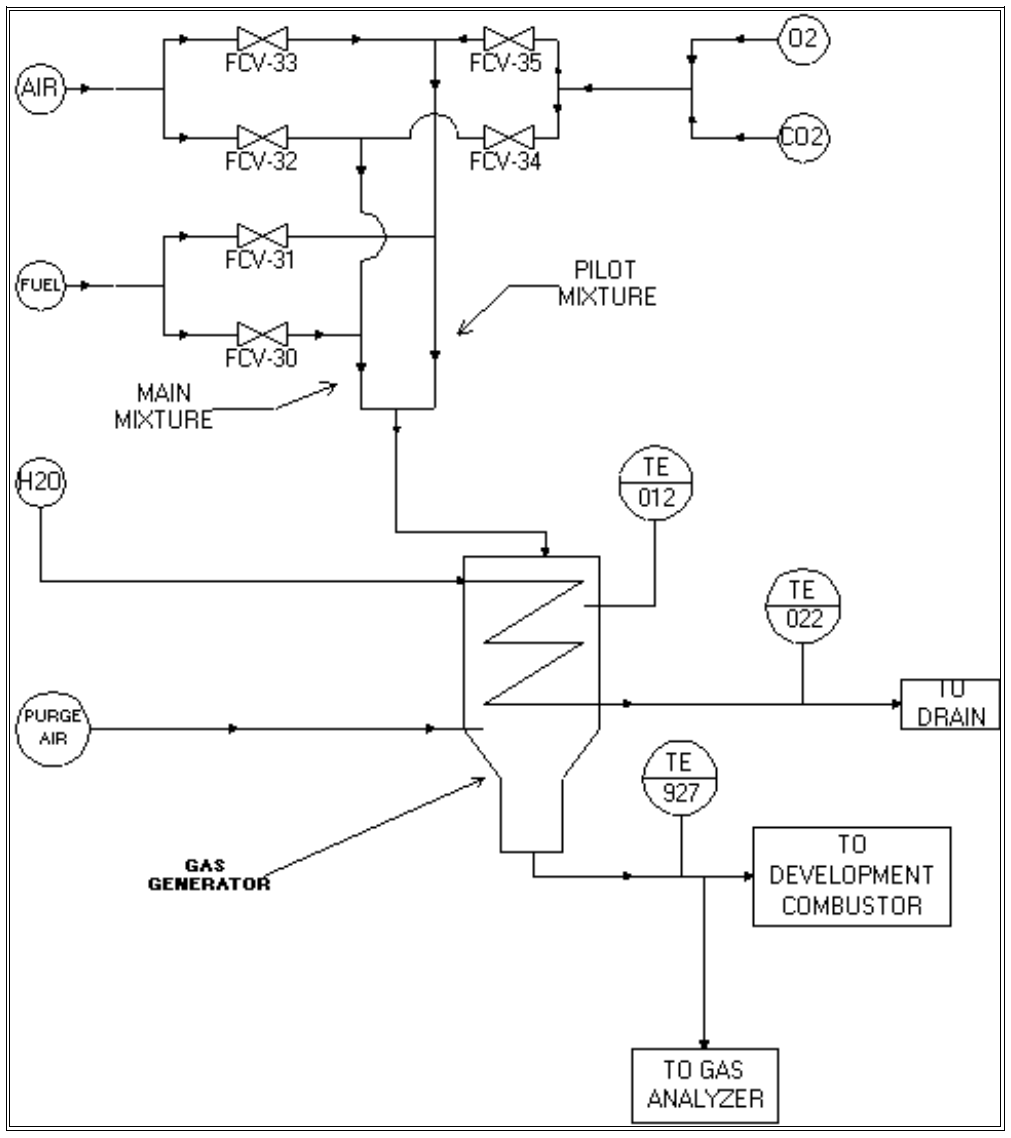

Figure 4. Schematic of Gas Generator 


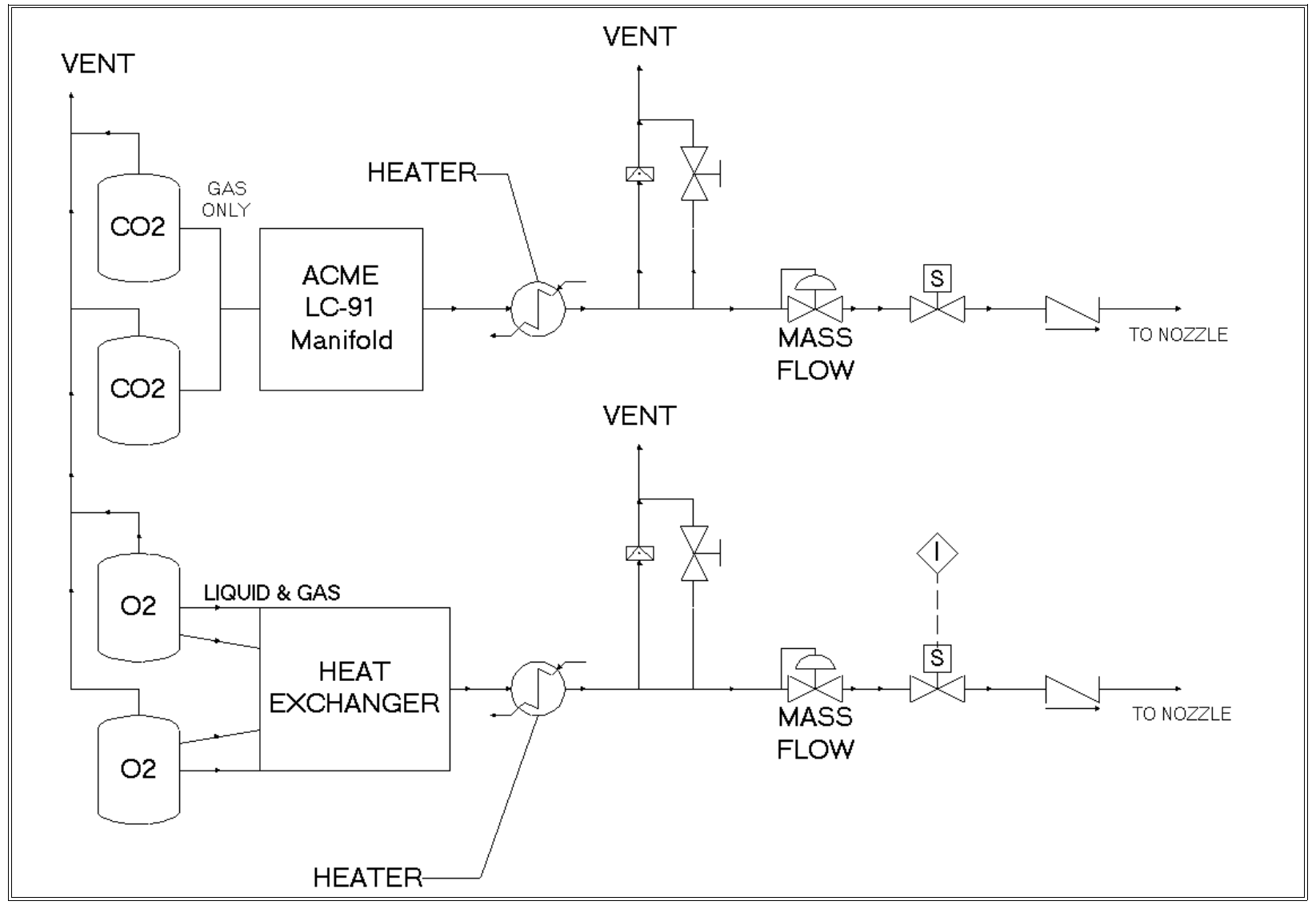

Figure 5. Schematic of Gas Generator Oxygen and Carbon Dioxide Supplies 


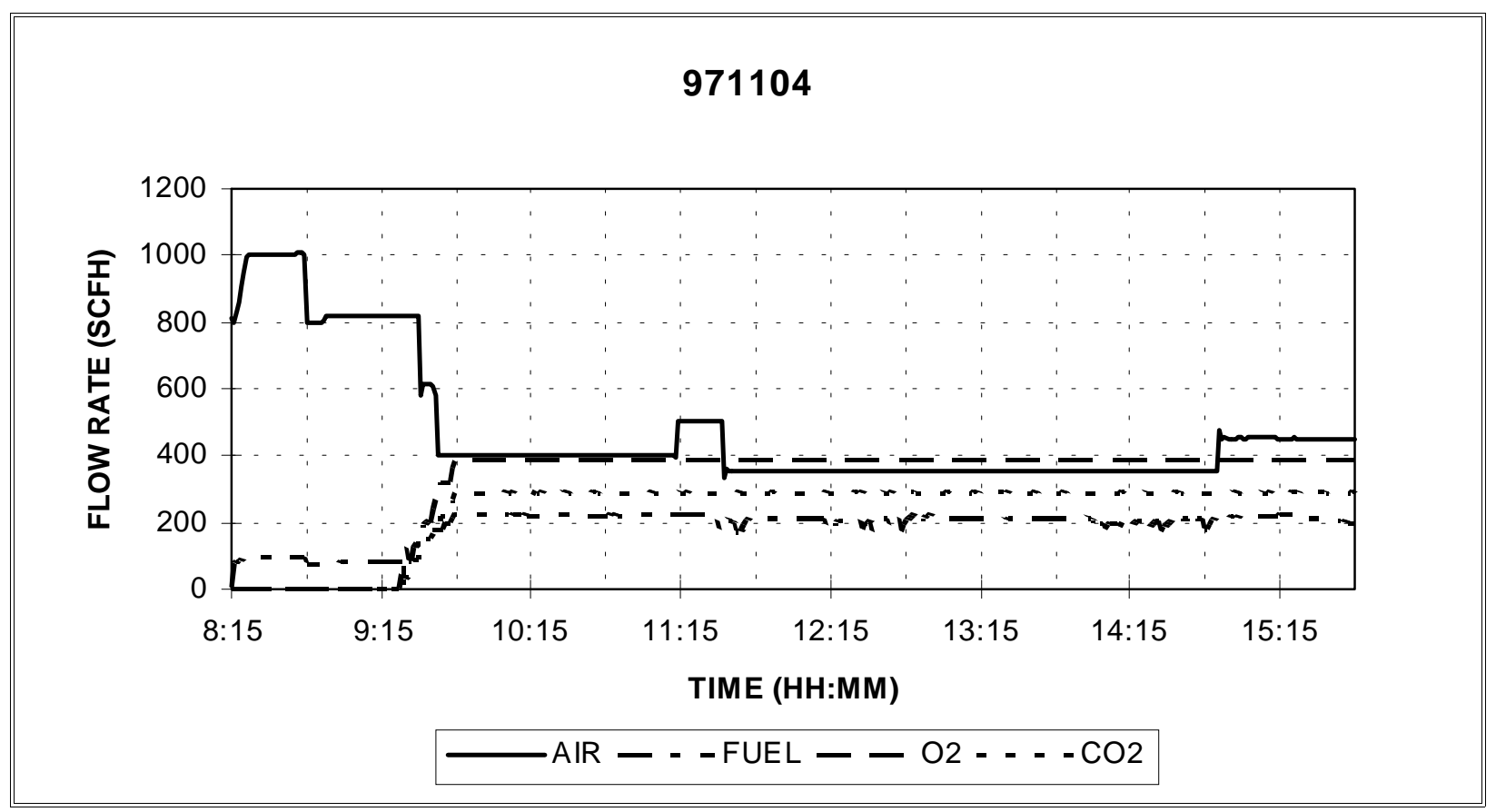

Figure 6a. Flow Rate History of a Typical Run

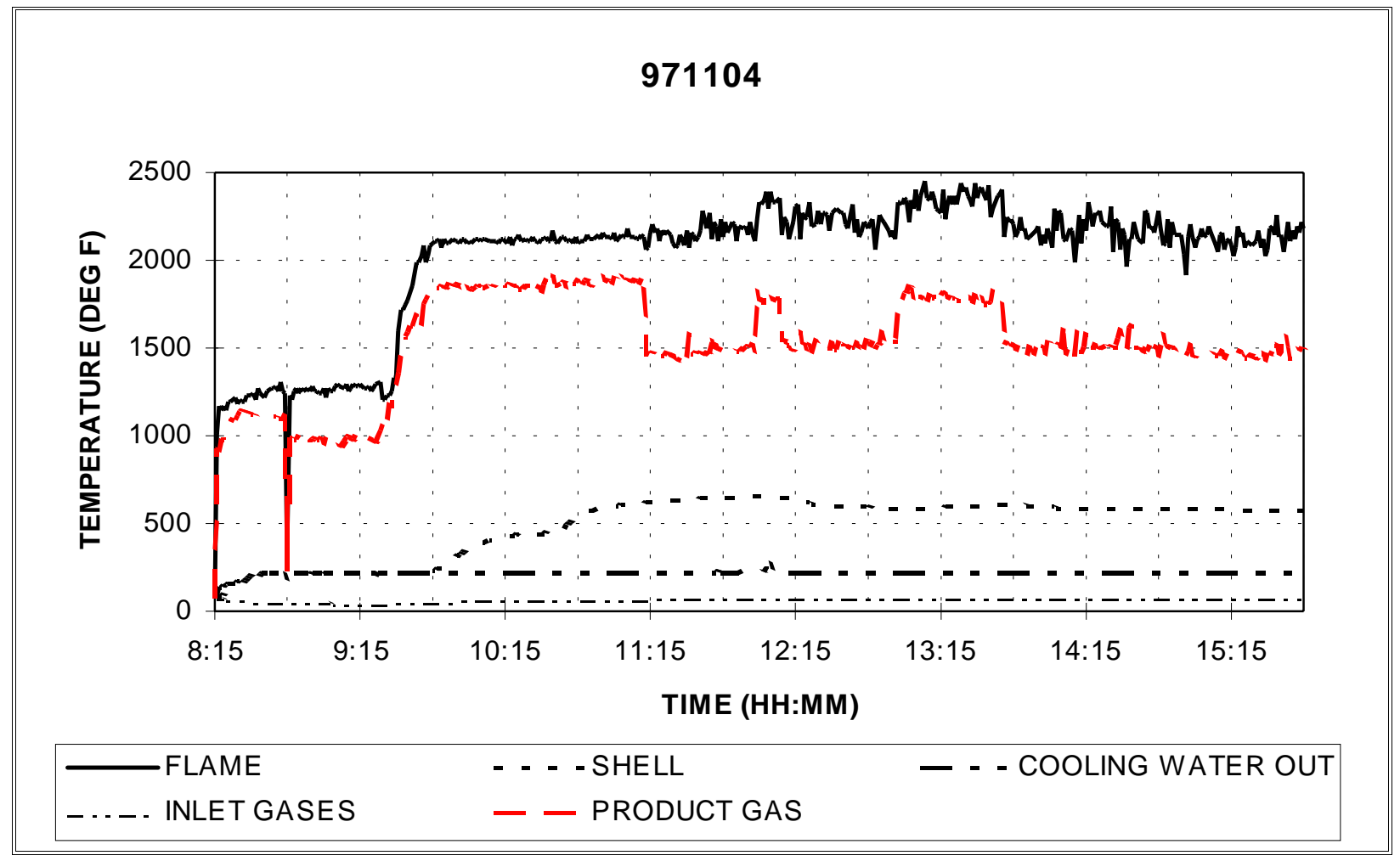

Figure 6b. Temperature History of a Typical Run 


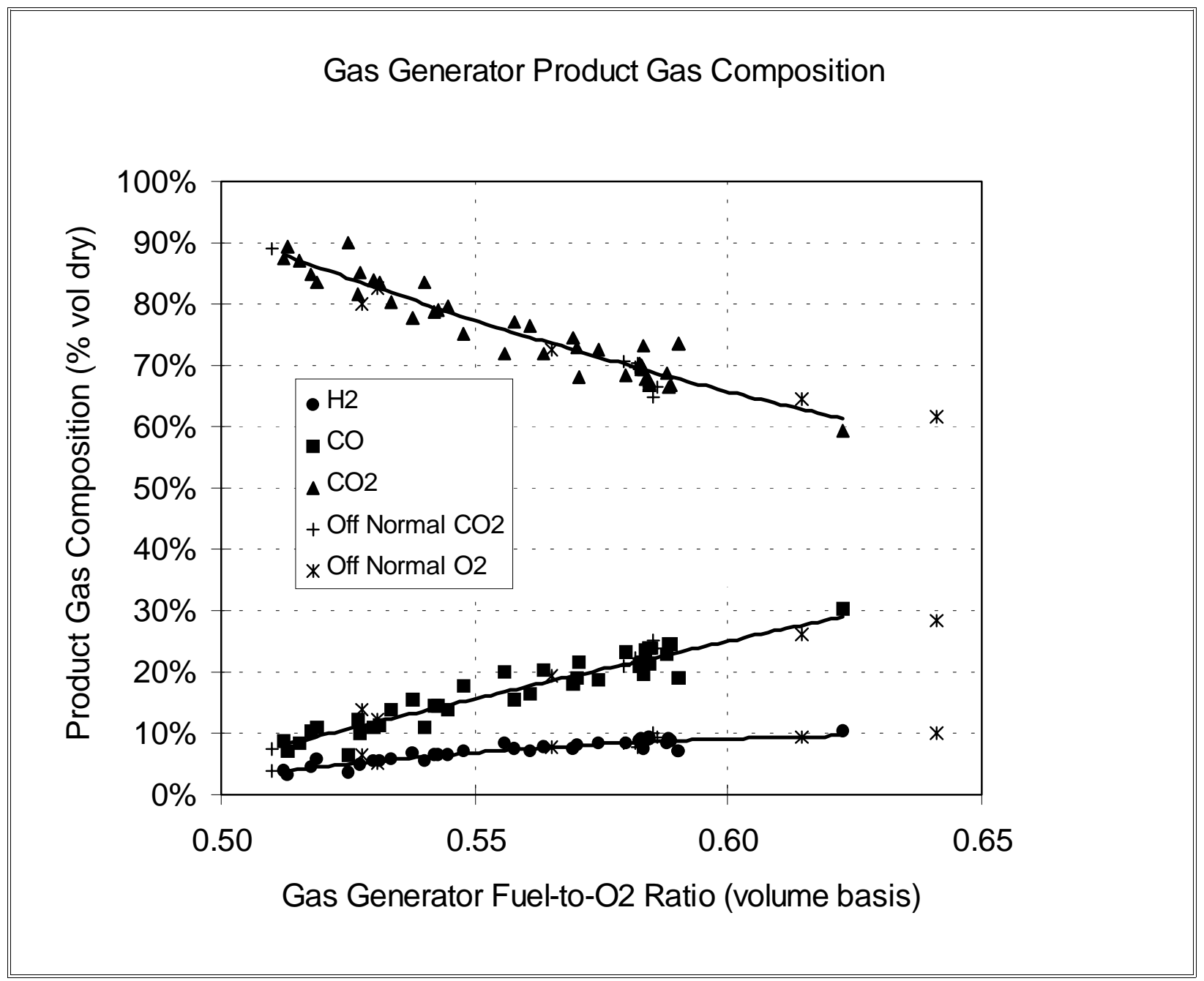

Figure 7. Product Gas Composition Versus Fuel-to-Oxygen Ratio 


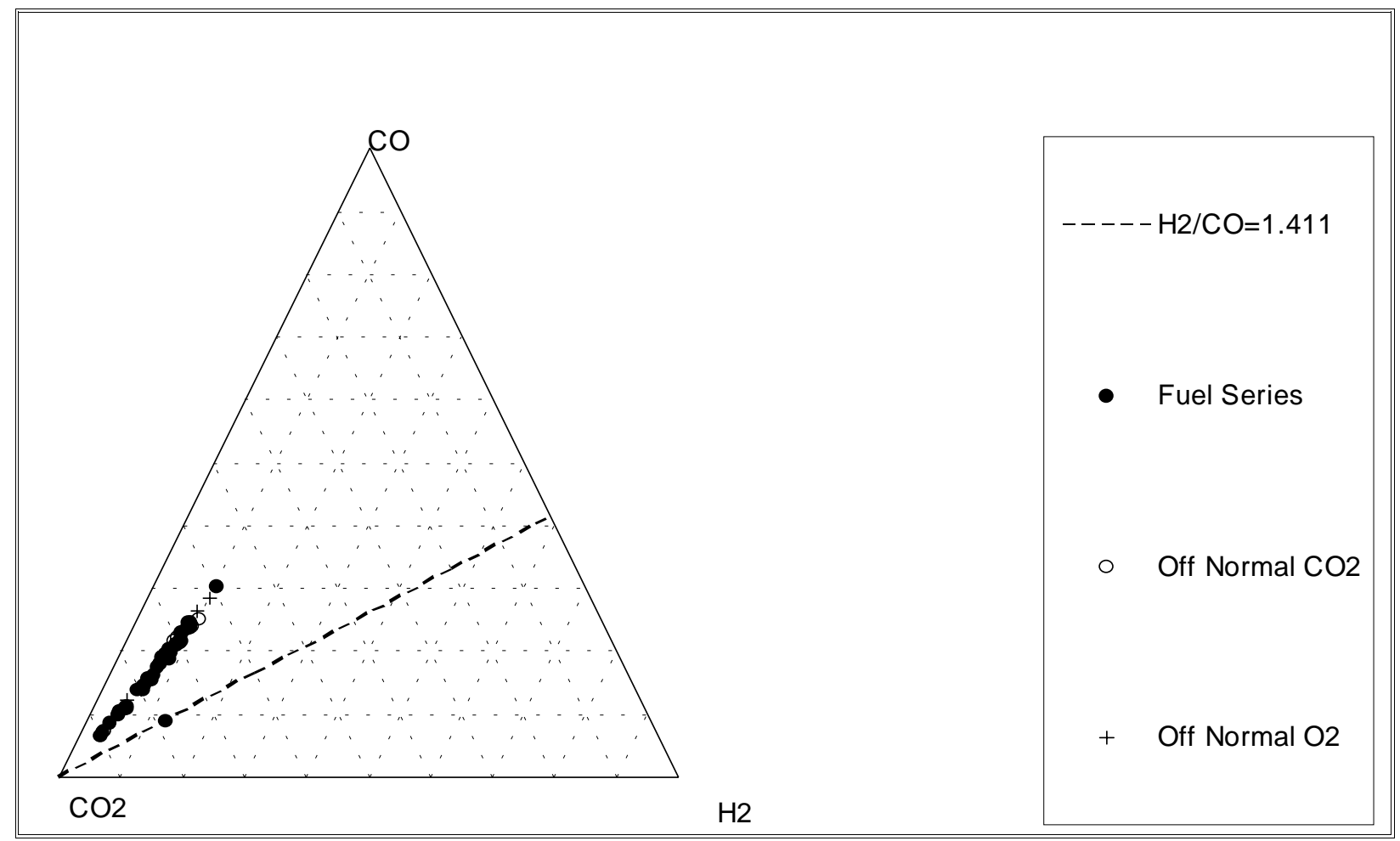

Figure 8. Ternary Plot of Product Gas Compositions (Volume Basis, Dry)

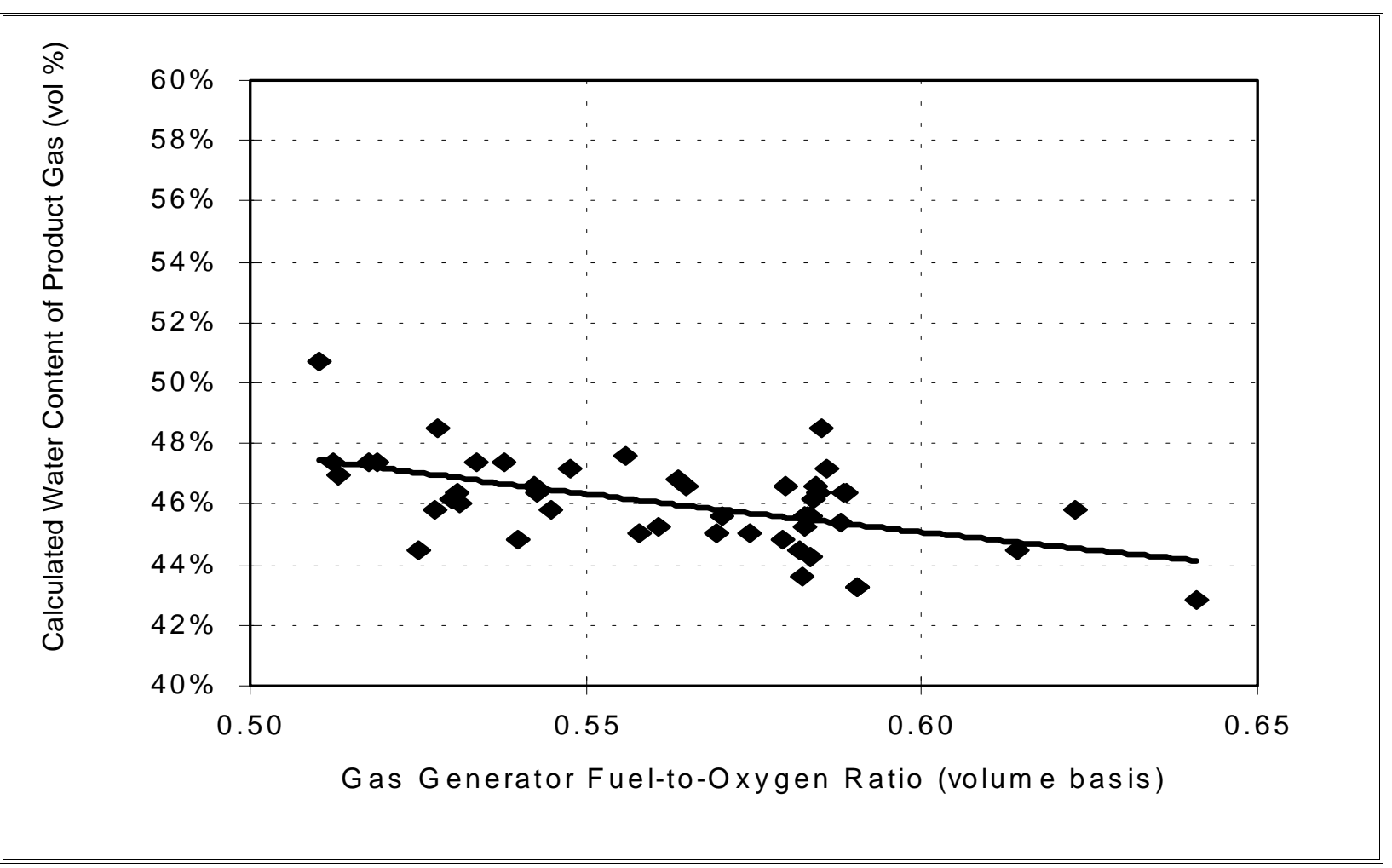

Figure 9. Water Vapor Content of Product Gases 


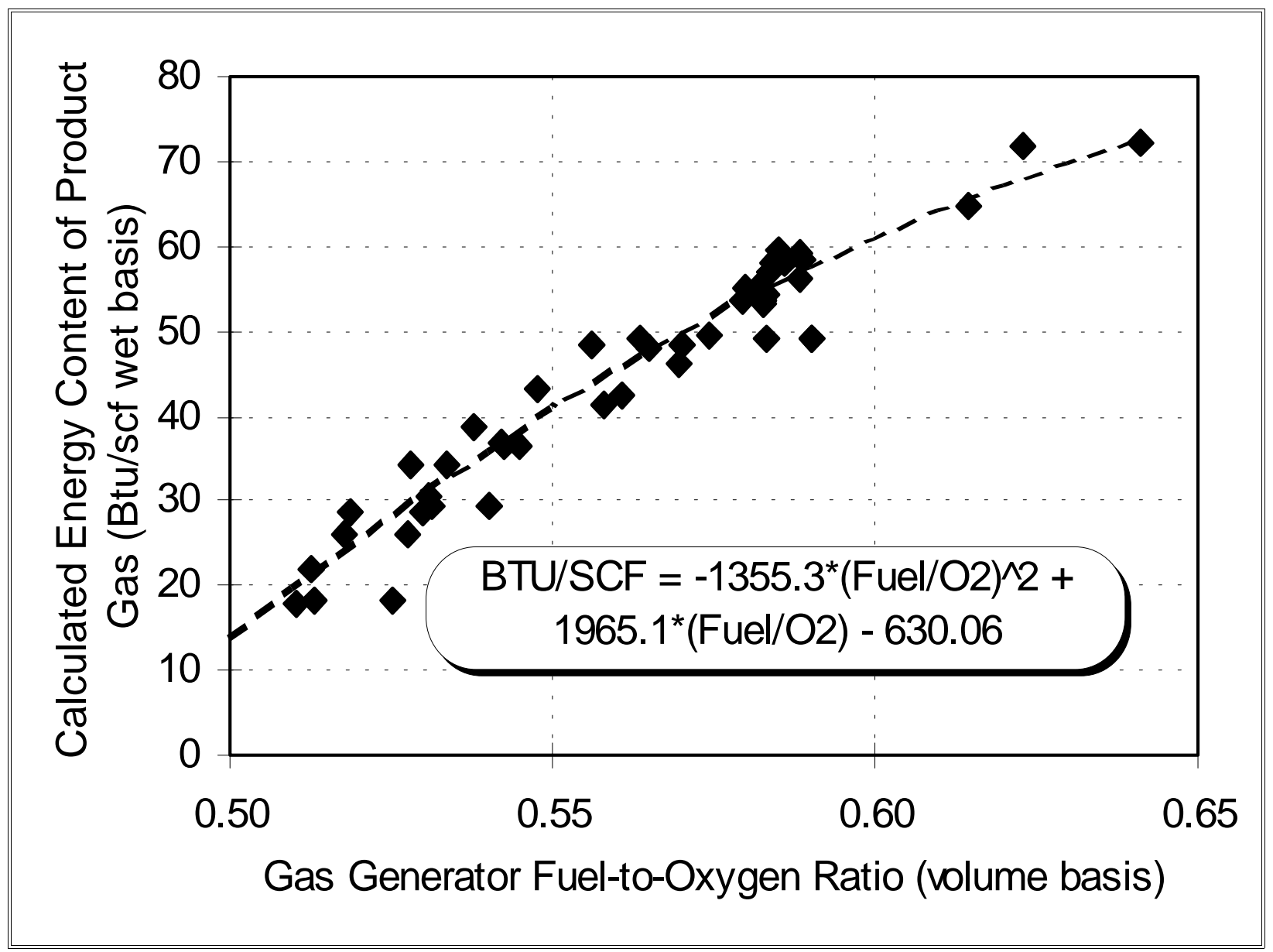

Figure 10. Energy Content (Wet Basis) of Product Gases

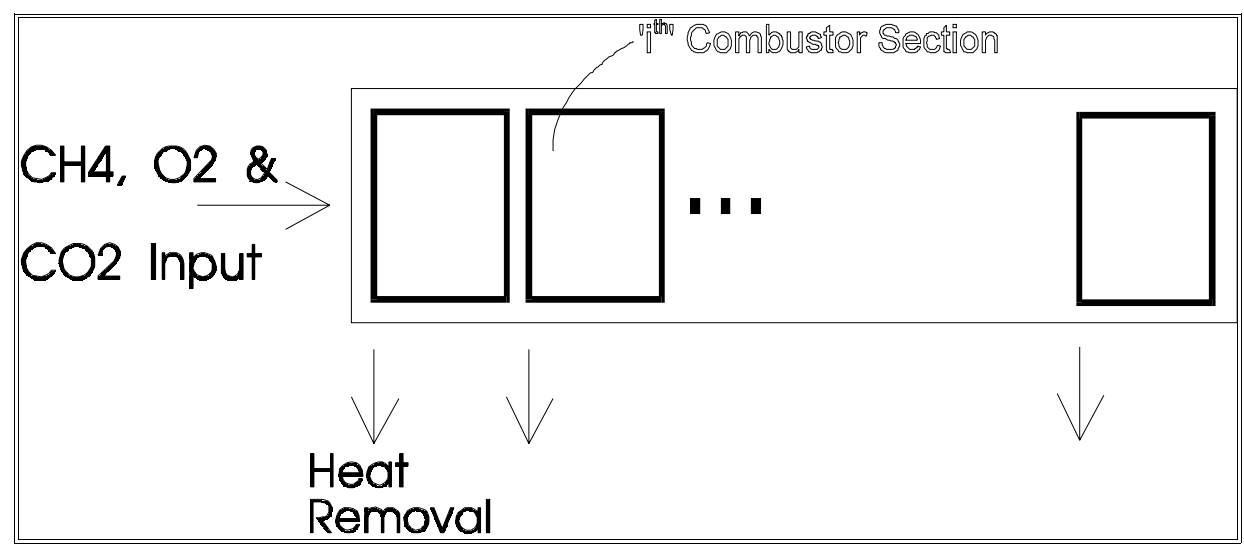

Figure 11. Numerical Model Description 
(80 deg. F/in. Heat Removal Rate)

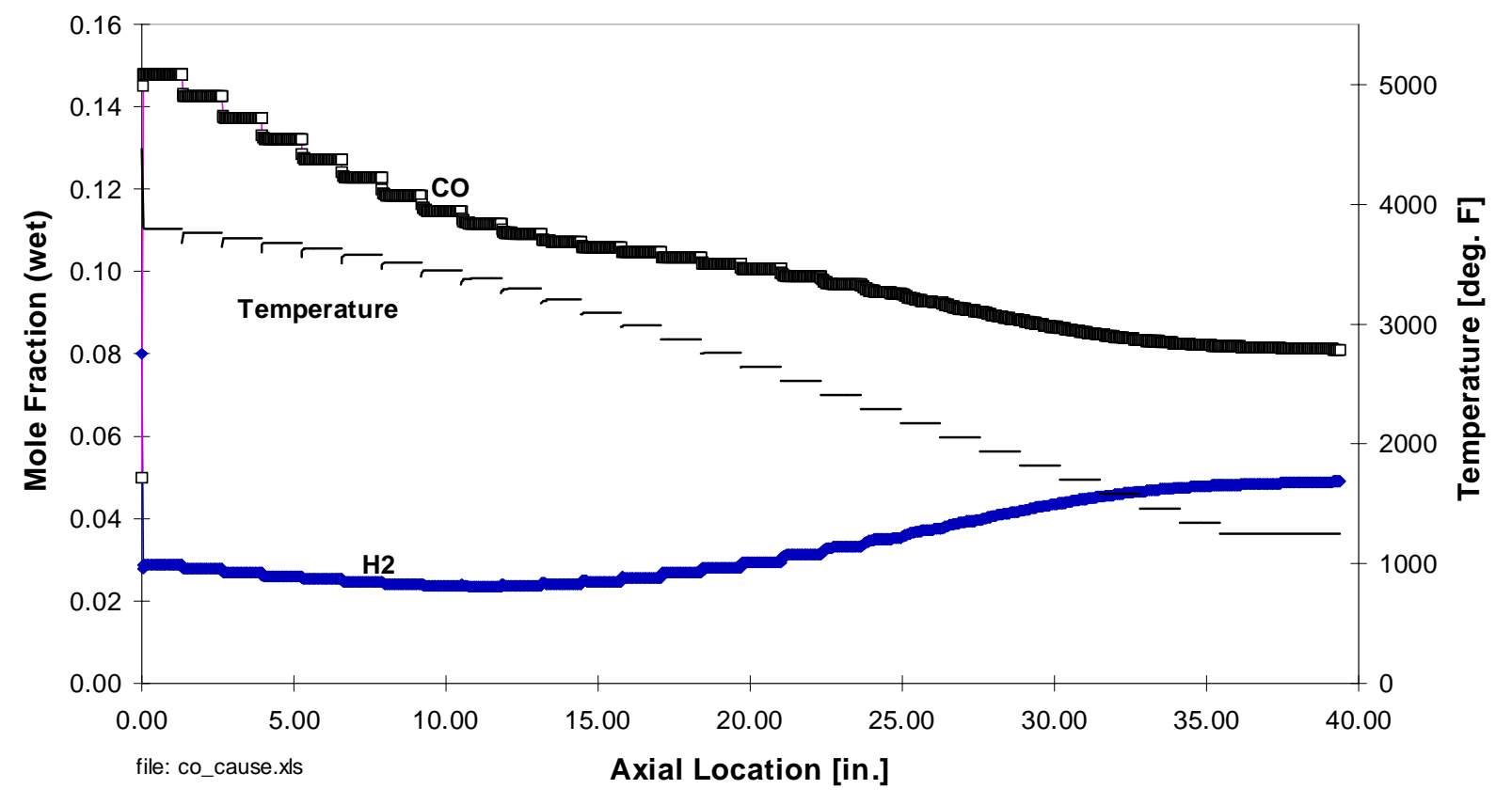

Figure 12. Model Results Showing Quenching of $\mathrm{CO}$ and $\mathrm{H}_{2}$ Inside the Gas Generator

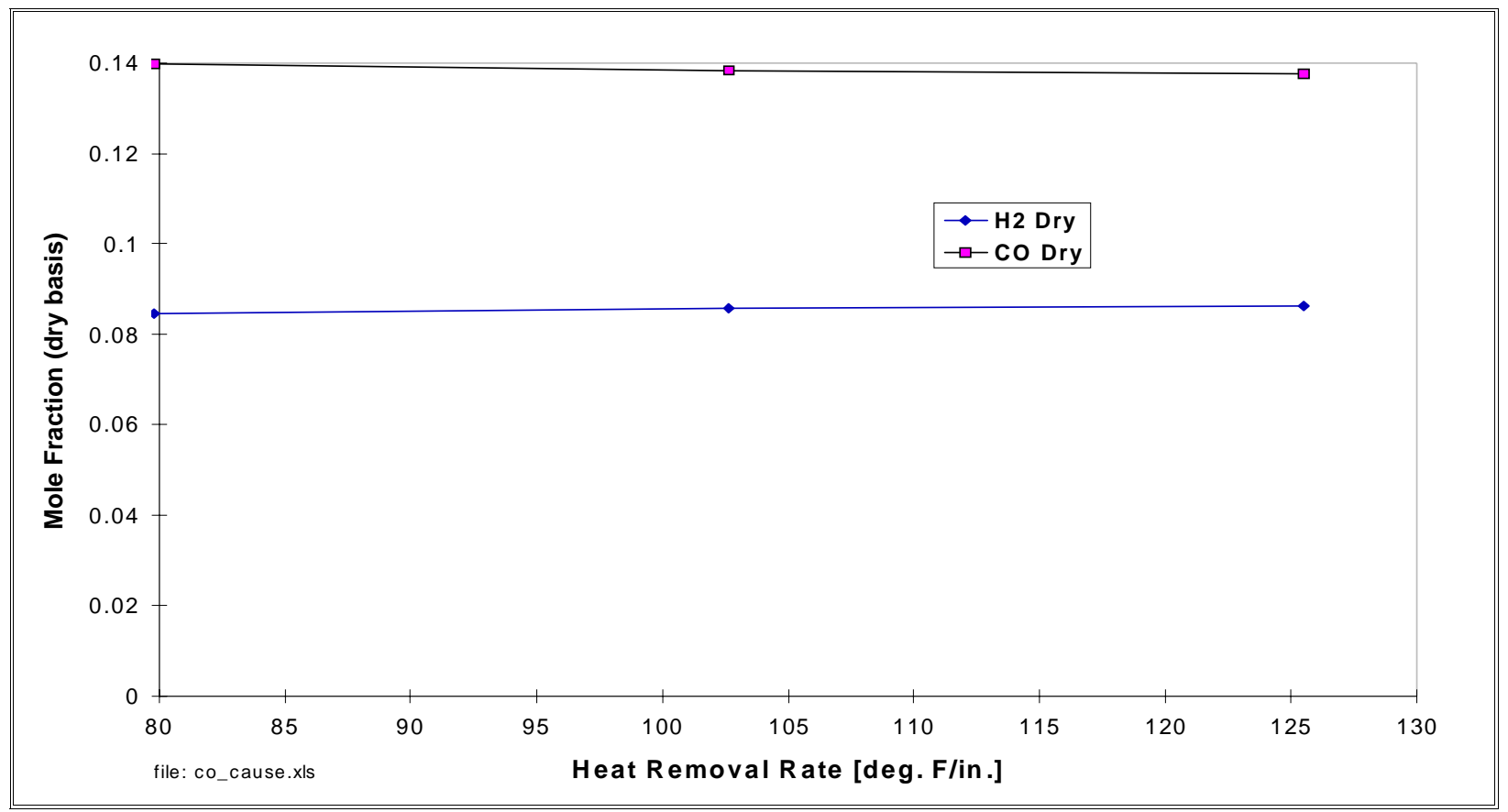

Figure 13. The Effect of Heat Rate on $\mathrm{CO}$ and $\mathrm{H}_{2}$ Predictions 
Tables

Table 1. Initial Valve Settings for the Gas Generator Nozzle

\begin{tabular}{|c|c|c|c|}
\hline Tag Number & Description & $\begin{array}{c}\text { Whitey Valve } \\
\text { Model }\end{array}$ & $\begin{array}{c}\text { Initial Position } \\
\text { (turns open) }\end{array}$ \\
\hline FCV-30 & Main fuel & SS-1VS4 & 0.50 \\
\hline FCV-31 & Pilot fuel & SS-ORS2 & 3.10 \\
\hline FCV-32 & Main air & SS-1VS6 & 0.50 \\
\hline FCV-33 & Pilot air & SS-ORS2 & 7.25 \\
\hline FCV-34 & $\begin{array}{c}\text { Main } \mathrm{O}_{2} / \mathrm{CO}_{2} \\
\text { (a.k.a. "LPM Split") }\end{array}$ & SS-1VS6 & 0.25 \\
\hline FCV-35 & Pilot $\mathrm{O}_{2} / \mathrm{CO}_{2}$ & SS-ORS2 & 8.50 \\
& & & (full open) \\
\hline
\end{tabular}

26 


\section{Table 2. Transition Steps from Start-Up to Normal Gas Generator Operation}

\begin{tabular}{|c|c|c|}
\hline Step \# & Description & $\begin{array}{c}\text { O2/Fuel } \\
\text { Ratio } \\
\end{array}$ \\
\hline 0 & Starting point $(800 \mathrm{scf} / \mathrm{h}$ air, $75 \mathrm{scf} / \mathrm{h}$ fuel $)$ & 2.24 \\
\hline 1 & $\mathrm{O}_{2}$ to $40 \mathrm{scf} / \mathrm{h}$ & 2.78 \\
\hline 2 & Fuel to $85 \mathrm{scf} / \mathrm{h}$ & 2.42 \\
\hline 3 & $\mathrm{CO}_{2}$ to $30 \mathrm{scf} / \mathrm{h}$ & 2.42 \\
\hline 4 & Fuel to $95 \mathrm{scf} / \mathrm{h}$ & 2.17 \\
\hline 5 & $\mathrm{O}_{2}$ to $80 \mathrm{scf} / \mathrm{h}$ & 2.59 \\
\hline 6 & $\mathrm{CO}_{2}$ to $60 \mathrm{scf} / \mathrm{h}$ & 2.59 \\
\hline 7 & Fuel to $115 \mathrm{scf} / \mathrm{h}$ & 2.14 \\
\hline 8 & $\mathrm{O}_{2}$ to $120 \mathrm{scf} / \mathrm{h}$ & 2.49 \\
\hline 9 & $\mathrm{CO}_{2}$ to $90 \mathrm{scf} / \mathrm{h}$ & 2.49 \\
\hline \multirow[t]{2}{*}{10} & Fuel to $135 \mathrm{scf} / \mathrm{h}$ & 2.12 \\
\hline & Open LPM split (FCV-34) to one full turn (total) & \\
\hline 11 & $\mathrm{O}_{2}$ to $160 \mathrm{scf} / \mathrm{h}$ & 2.41 \\
\hline 12 & $\mathrm{CO}_{2}$ to $120 \mathrm{scf} / \mathrm{h}$ & 2.41 \\
\hline 13 & Air to $600 \mathrm{scf} / \mathrm{h}$ & 2.11 \\
\hline 14 & $\mathrm{O}_{2}$ to $200 \mathrm{scf} / \mathrm{h}$ & 2.41 \\
\hline 15 & $\mathrm{CO}_{2}$ to $150 \mathrm{scf} / \mathrm{h}$ & 2.41 \\
\hline \multirow[t]{2}{*}{16} & Fuel to $155 \mathrm{scf} / \mathrm{h}$ & 2.10 \\
\hline & Open LPM split by another $1 / 4$ turn & \\
\hline 17 & $\mathrm{O}_{2}$ to $240 \mathrm{scf} / \mathrm{h}$ & 2.35 \\
\hline 18 & $\mathrm{CO}_{2}$ to $180 \mathrm{scf} / \mathrm{h}$ & 2.35 \\
\hline 19 & Fuel to $175 \mathrm{scf} / \mathrm{h}$ & 2.08 \\
\hline 20 & $\mathrm{O}_{2}$ to $280 \mathrm{scf} / \mathrm{h}$ & 2.31 \\
\hline 21 & $\mathrm{CO}_{2}$ to $210 \mathrm{scf} / \mathrm{h}$ & 2.31 \\
\hline \multirow[t]{2}{*}{22} & Air to $400 \mathrm{scf} / \mathrm{h}$ & 2.08 \\
\hline & Turn supplement $\mathrm{CO}_{2}$ heating elements $\mathrm{ON}$ & \\
\hline 23 & $\mathrm{O}_{2}$ to $320 \mathrm{scf} / \mathrm{h}$ (incr. supply press. to $100 \mathrm{psig}$ ) & 2.30 \\
\hline 24 & $\mathrm{CO}_{2}$ to $240 \mathrm{scf} / \mathrm{h}$ & 2.30 \\
\hline \multirow[t]{2}{*}{25} & Fuel to $195 \mathrm{scf} / \mathrm{h}$ & 2.07 \\
\hline & Open LPM another 3/4 turn ( two turns total) & \\
\hline 26 & $\mathrm{O}_{2}$ to $360 \mathrm{scf} / \mathrm{h}$ & 2.27 \\
\hline 27 & $\mathrm{CO}_{2}$ to $270 \mathrm{scf} / \mathrm{h}$ & 2.27 \\
\hline 28 & Fuel to $215 \mathrm{scf} / \mathrm{h}$ & 2.06 \\
\hline 29 & $\mathrm{O}_{2}$ to $386 \mathrm{scf} / \mathrm{h}$ & 2.18 \\
\hline 30 & $\mathrm{CO}_{2}$ to $289 \mathrm{scf} / \mathrm{h}$ & 2.18 \\
\hline 31 & Fuel to $225 \mathrm{scf} / \mathrm{h}$ & 2.09 \\
\hline 32 & Shut off air to GG & 1.72 \\
\hline 33 & Purge air OFF & 1.72 \\
\hline
\end{tabular}




\section{Table 3. Analysis of Product Gas Composition}

\begin{tabular}{|c|c|c|c|c|c|c|c|c|c|}
\hline \multirow{2}{*}{ Test Run } & \multirow{2}{*}{ Sample Description } & \multirow{2}{*}{$\begin{array}{c}\text { Sample } \\
\text { Time } \\
\text { (hh:mm) }\end{array}$} & \multirow{2}{*}{$\begin{array}{l}\text { Report } \\
\text { Number }\end{array}$} & \multicolumn{3}{|c|}{$\begin{array}{c}\text { Normalized Gas } \\
\text { Composition (\% Vol Dry) }\end{array}$} & \multicolumn{3}{|c|}{$\begin{array}{l}\text { Feedstock Flow Rates } \\
(\mathrm{scf} / \mathrm{h})\end{array}$} \\
\hline & & & & $\mathrm{H}_{2}$ & $\mathrm{CO}$ & $\mathrm{CO}_{2}$ & Fuel & $\mathrm{O}_{2}$ & $\mathrm{CO}_{2}$ \\
\hline 971104 & dc inlet sample & $15: 01$ & \#N/A & $8.3 \%$ & $19.9 \%$ & $71.8 \%$ & 215 & 387 & 290 \\
\hline 971104 & dc inlet sample & $15: 12$ & \#N/A & & $21.6 \%$ & $68.1 \%$ & 220 & 386 & 290 \\
\hline 971104 & dc inlet sample & $15: 20$ & \#N/A & & $21.4 \%$ & $67.4 \%$ & 226 & 386 & 289 \\
\hline 971104 & dc inlet sample & $15: 30$ & \#N/A & $7.2 \%$ & $17.6 \%$ & $75.2 \%$ & 212 & 386 & 289 \\
\hline 971104 & dc inlet sample & $15: 38$ & \#N/A & & $12.4 \%$ & $81.5 \%$ & 204 & 387 & 289 \\
\hline 971104 & dc inlet sample & $15: 44$ & \#N/A & & $8.5 \%$ & $87.0 \%$ & 199 & 386 & 290 \\
\hline 970808 & dc inlet sample & $12: 50$ & \#N/A & $8.0 \%$ & $19.0 \%$ & $73.0 \%$ & 220 & 386 & 289 \\
\hline 970808 & dc inlet sample & $13: 31$ & \#N/A & $7.4 \%$ & $15.4 \%$ & $77.2 \%$ & 215 & 386 & 289 \\
\hline 970808 & dc inlet sample & 14:14 & \#N/A & $6.6 \%$ & $13.8 \%$ & $79.6 \%$ & 210 & 386 & 289 \\
\hline 970808 & dc inlet sample & $14: 58$ & \#N/A & $5.4 \%$ & $11.1 \%$ & $83.5 \%$ & 205 & 386 & 289 \\
\hline 970808 & dc inlet sample & $15: 36$ & \#N/A & $3.5 \%$ & $6.4 \%$ & $90.0 \%$ & 203 & 386 & 289 \\
\hline 970701 & dc inlet sample & $12: 35$ & 0 & $8.5 \%$ & $18.9 \%$ & $72.6 \%$ & 222 & 386 & 289 \\
\hline 970625 & dc inlet sample & $14: 46$ & 0 & $7.2 \%$ & $16.3 \%$ & $76.4 \%$ & 216 & 386 & 289 \\
\hline 970625 & dc inlet sample & $15: 33$ & 1 & $5.4 \%$ & $10.9 \%$ & $83.7 \%$ & 205 & 387 & 288 \\
\hline 970617 & dc inlet sample & $11: 34$ & 1 & $6.4 \%$ & $14.4 \%$ & $79.2 \%$ & 210 & 386 & 289 \\
\hline 970617 & dc inlet sample & $13: 38$ & 2 & $4.8 \%$ & $9.9 \%$ & $85.3 \%$ & 203 & 385 & 289 \\
\hline 970617 & dc inlet sample & $15: 46$ & 3 & $7.5 \%$ & $18.0 \%$ & $74.6 \%$ & 219 & 385 & 290 \\
\hline 970610 & dc inlet sample & $11: 40$ & 1 & $7.8 \%$ & $20.3 \%$ & $71.9 \%$ & 218 & 386 & 290 \\
\hline 970610 & dc inlet sample & $15: 58$ & 2 & $5.7 \%$ & $10.9 \%$ & $83.4 \%$ & 200 & 386 & 290 \\
\hline 970530 & target fuel production & $13: 43$ & 1 & $6.7 \%$ & $15.6 \%$ & $77.7 \%$ & 208 & 386 & 289 \\
\hline 970530 & target post catalyst & $15: 35$ & 4 & $5.3 \%$ & $11.0 \%$ & $83.7 \%$ & 209 & 386 & 291 \\
\hline 970521 & base conditions & $13: 10$ & 0 & $8.7 \%$ & $21.8 \%$ & $69.5 \%$ & 225 & 386 & 289 \\
\hline 970521 & base conditions & $13: 40$ & 1 & $8.9 \%$ & $21.8 \%$ & $69.4 \%$ & 225 & 386 & 289 \\
\hline 970521 & case conditions & 14:10 & 2 & $8.6 \%$ & $21.0 \%$ & $70.5 \%$ & 225 & 386 & 288 \\
\hline 970520 & inlet gas (base?) & $14: 08$ & 1 & $7.4 \%$ & $19.5 \%$ & $73.1 \%$ & 225 & 386 & 295 \\
\hline 970520 & inlet (LPM open) & $14: 40$ & 2 & $8.5 \%$ & $22.8 \%$ & $68.7 \%$ & 226 & 385 & 291 \\
\hline 970520 & inlet (LPM restricted) & $15: 10$ & 3 & $9.3 \%$ & $23.8 \%$ & $66.9 \%$ & 225 & 386 & 290 \\
\hline 970520 & inlet (base) & $15: 42$ & 4 & $9.0 \%$ & $24.6 \%$ & $66.5 \%$ & 227 & 386 & 289 \\
\hline 970520 & inlet (restricted cooling) & $16: 12$ & 5 & $8.9 \%$ & $23.4 \%$ & $67.8 \%$ & 225 & 385 & 289 \\
\hline 970520 & inlet (base) & $16: 41$ & 6 & $9.0 \%$ & $23.8 \%$ & $67.2 \%$ & 225 & 385 & 289 \\
\hline 970513 & base $-20 \% \mathrm{CO}_{2}$ & $14: 30$ & 5 & $10.1 \%$ & $25.2 \%$ & $64.8 \%$ & 226 & 386 & 231 \\
\hline
\end{tabular}


Table 3. Analysis of Product Gas Composition (continued)

\begin{tabular}{|c|c|c|c|c|c|c|c|c|c|}
\hline \multirow{2}{*}{ Test Run } & \multirow{2}{*}{ Sample Description } & \multirow{2}{*}{$\begin{array}{l}\text { Sample } \\
\text { Time } \\
\text { (hh:mm) }\end{array}$} & \multirow{2}{*}{$\begin{array}{l}\text { Report } \\
\text { Number }\end{array}$} & \multicolumn{3}{|c|}{$\begin{array}{c}\text { Normalized Gas } \\
\text { Composition (\% Vol Dry) }\end{array}$} & \multicolumn{3}{|c|}{$\begin{array}{l}\text { Feedstock Flow Rates } \\
(\mathrm{scf} / \mathrm{h})\end{array}$} \\
\hline & & & & $\mathrm{H}_{2}$ & $\mathrm{CO}$ & $\mathrm{CO}_{2}$ & Fuel & $\mathrm{O}_{2}$ & $\mathrm{CO}_{2}$ \\
\hline 970513 & base $-10 \% \mathrm{CO}_{2}$ & 14:03 & 4 & $9.5 \%$ & $24.0 \%$ & $66.5 \%$ & 226 & 386 & 260 \\
\hline 970513 & base & $11: 45$ & 0 & $8.7 \%$ & $21.4 \%$ & $69.9 \%$ & 225 & 387 & 286 \\
\hline 970513 & base & 17:00 & 10 & $7.3 \%$ & $19.1 \%$ & $73.6 \%$ & 227 & 384 & 290 \\
\hline 970513 & base $+10 \% \mathrm{CO}_{2}$ & $12: 19$ & 1 & $8.4 \%$ & $21.1 \%$ & $70.5 \%$ & 224 & 386 & 320 \\
\hline 970513 & base $+20 \% \mathrm{CO}_{2}$ & $12: 55$ & 2 & $8.2 \%$ & $22.1 \%$ & $69.7 \%$ & 224 & 386 & 348 \\
\hline 970513 & base $+30 \% \mathrm{CO}_{2}$ & $13: 28$ & 3 & $7.8 \%$ & $21.7 \%$ & $70.5 \%$ & 225 & 386 & 374 \\
\hline 970513 & base $-8 \% \mathrm{O}_{2}$ & $16: 31$ & 9 & $10.0 \%$ & $28.5 \%$ & $61.5 \%$ & 228 & 355 & 288 \\
\hline 970513 & base $-4 \% \mathrm{O}_{2}$ & 16:00 & 8 & $9.3 \%$ & $26.3 \%$ & $64.4 \%$ & 227 & 370 & 287 \\
\hline 970513 & base & 11:45 & 0 & $8.7 \%$ & $21.4 \%$ & $69.9 \%$ & 225 & 387 & 286 \\
\hline 970513 & base & 17:00 & 10 & $7.3 \%$ & $19.1 \%$ & $73.6 \%$ & 227 & 384 & 290 \\
\hline 970513 & base $+4 \% \mathrm{O}_{2}$ & 15:00 & 6 & $7.9 \%$ & $19.4 \%$ & $72.7 \%$ & 226 & 400 & 288 \\
\hline 970513 & base $+8 \% \mathrm{O}_{2}$ & $15: 30$ & 7 & $6.4 \%$ & $13.8 \%$ & $79.8 \%$ & 222 & 420 & 287 \\
\hline 970512 & base $-15 \mathrm{scf} / \mathrm{h}$ fuel & 15:06 & 4 & $6.5 \%$ & $14.6 \%$ & $78.9 \%$ & 209 & 386 & 285 \\
\hline 970512 & base & $14: 30$ & 3 & $8.4 \%$ & $23.1 \%$ & $68.5 \%$ & 225 & 387 & 287 \\
\hline 970512 & base $+15 \mathrm{scf} / \mathrm{h}$ fuel & $15: 55$ & 5 & $10.2 \%$ & $30.3 \%$ & $59.5 \%$ & 241 & 386 & 289 \\
\hline 970512 & inlet & 14:03 & 2 & $8.8 \%$ & $24.5 \%$ & $66.8 \%$ & 228 & 387 & 287 \\
\hline 970423 & POC & 12:07 & 0 & $9.2 \%$ & $24.0 \%$ & $66.9 \%$ & 226 & 386 & \\
\hline 970423 & POC & $13: 13$ & 1 & $3.9 \%$ & $8.7 \%$ & $87.4 \%$ & 198 & 387 & 282 \\
\hline 970423 & POC & $13: 45$ & 2 & $4.6 \%$ & $10.4 \%$ & $84.9 \%$ & 200 & 386 & 286 \\
\hline 970423 & POC & 14:11 & 3 & $5.9 \%$ & $13.9 \%$ & $80.2 \%$ & 207 & 387 & 282 \\
\hline 970423 & POC & $14: 40$ & 4 & $3.7 \%$ & $7.3 \%$ & $89.0 \%$ & 197 & 387 & 208 \\
\hline 970423 & POC & $15: 14$ & 5 & $3.4 \%$ & $7.1 \%$ & $89.5 \%$ & 198 & 386 & 275 \\
\hline 970423 & POC & $15: 43$ & 6 & $5.1 \%$ & $12.2 \%$ & $82.7 \%$ & 200 & 376 & 289 \\
\hline
\end{tabular}




\section{Appendix}

QuickBASIC Code used to calculate water vapor content of product gases by balancing mass flow of oxygen.

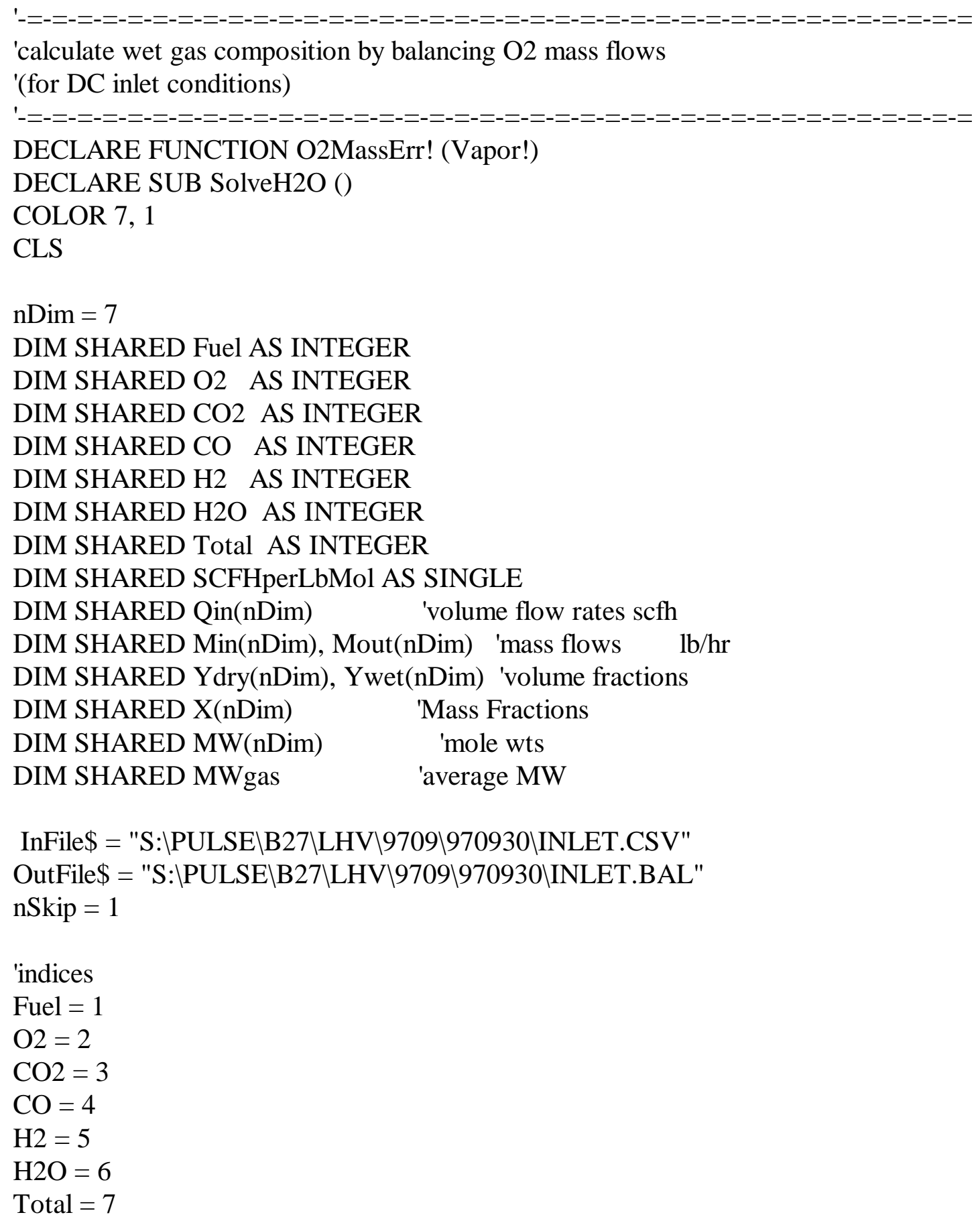




$$
\begin{aligned}
& \text { 'Specify Mole Wt } \\
& \text { MW(Fuel }=12.0112+4 * 1.00797 \\
& \text { MW(O2) }=2 * 15.9994 \\
& \text { MW(CO2) }=12.0112+2 * 15.9994 \\
& \text { MW(CO) }=12.0112+15.9994 \\
& \text { MW(H2) }=2 * 1.00797 \\
& \text { MW(H2O) }=2 * 1.00797+15.9994 \\
& \text { SCFHperLbMol }=379.2
\end{aligned}
$$

OPEN InFile\$ FOR INPUT AS \#3

IF nSkip > 0 THEN

FOR $\mathrm{i}=1$ TO nSkip

LINE INPUT \#3, junk\$

NEXT i

END IF

OPEN OutFile\$ FOR OUTPUT AS \#4

PRINT \#4, "Q(Fuel),";

PRINT \#4, "Q(O2),";

PRINT \#4, "Q(CO2),";

PRINT \#4, "Ydry(CO2),";

PRINT \#4, "Ydry(CO),";

PRINT \#4, "Ydry(H2),";

PRINT \#4, "Ydry(O2),";

PRINT \#4, "Ywet(CO2),";

PRINT \#4, "Ywet(CO),";

PRINT \#4, "Ywet(H2),";

PRINT \#4, "Ywet(O2),";

PRINT \#4, "Ywet(H2O),";

PRINT \#4, "TotVol (scfh)"

DO UNTIL EOF(3)

'Input the data

INPUT \#3, Q(Fuel), Q(O2), Q(CO2), Ydry(CO2), Ydry(CO), Ydry(H2), Ydry(O2)

'Calculate Common Quantities

Min (Fuel $)=Q($ Fuel $) *$ MW(Fuel $/$ SCFHperLbMol

$\operatorname{Min}(\mathrm{O} 2)=\mathrm{Q}(\mathrm{O} 2) * \operatorname{MW}(\mathrm{O} 2) / \mathrm{SCFHperLbMol}$

$\operatorname{Min}(\mathrm{CO} 2)=\mathrm{Q}(\mathrm{CO} 2) * \mathrm{MW}(\mathrm{CO} 2) / \mathrm{SCFHperLbMol}$

$\operatorname{Min}($ Total $)=\operatorname{Min}($ Fuel $)+\operatorname{Min}(\mathrm{O} 2)+\operatorname{Min}(\mathrm{CO} 2)$ 
'Solve for amount of water to balance $\mathrm{O} 2$ mass flows

CALL SolveH2O

PRINT

PRINT "Species

Dry Wet"

PRINT USING "I

\#.\#\#\#\#

\#.\#\#\#\# "; "CO2"; Ydry(CO2); Ywet(CO2)

PRINT USING "।

\#.\#\#\#\#

\#.\#\#\#\# "; "CO"; Ydry(CO); Ywet(CO)

PRINT USING "।

\#.\#\#\#\#

\#.\#\#\# "; "H2"; Ydry(H2); Ywet(H2)

PRINT USING "I

\#.\#\#\#\#

\#.\#\#\#\# "; "O2"; Ydry(O2); Ywet(O2)

PRINT USING "।

SLEEP

\#.\#\#\#

\#.\#\#\#\# "; "H2O"; 0; Ywet(H2O)

'write results out to file

PRINT \#4, Q(Fuel); ",";

PRINT \#4, Q(O2); ",";

PRINT \#4, Q(CO2); ",";

PRINT \#4, Ydry(CO2); ",";

PRINT \#4, Ydry(CO); ",";

PRINT \#4, Ydry(H2); ",";

PRINT \#4, Ydry(O2); ",";

PRINT \#4, Ywet(CO2); ",";

PRINT \#4, Ywet(CO); ",";

PRINT \#4, Ywet(H2); ",";

PRINT \#4, Ywet(O2); ",";

PRINT \#4, Ywet(H2O); ",";

MWgas $=0$

MWgas $=$ MWgas + Ywet $(\mathrm{CO} 2) * \mathrm{MW}(\mathrm{CO} 2)$

MWgas $=$ MWgas + Ywet $(\mathrm{CO}) * \mathrm{MW}(\mathrm{CO})$

MWgas $=$ MWgas + Ywet $(\mathrm{H} 2) * \mathrm{MW}(\mathrm{H} 2)$

MWgas $=$ MWgas + Ywet $(\mathrm{O} 2) * \mathrm{MW}(\mathrm{O} 2)$

MWgas $=$ MWgas + Ywet $(\mathrm{H} 2 \mathrm{O}) * \mathrm{MW}(\mathrm{H} 2 \mathrm{O})$

TotVol $=$ Min(Total $) *$ SCFHperLbMol $/$ MWgas

PRINT \#4, TotVol

\section{LOOP}

CLOSE 4

CLOSE 3 
FUNCTION O2MassErr (Vapor)

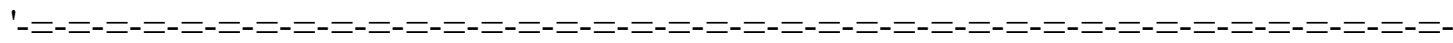

'Calculate Oxygen Mass Balance Error as a function of Water Vapor Content

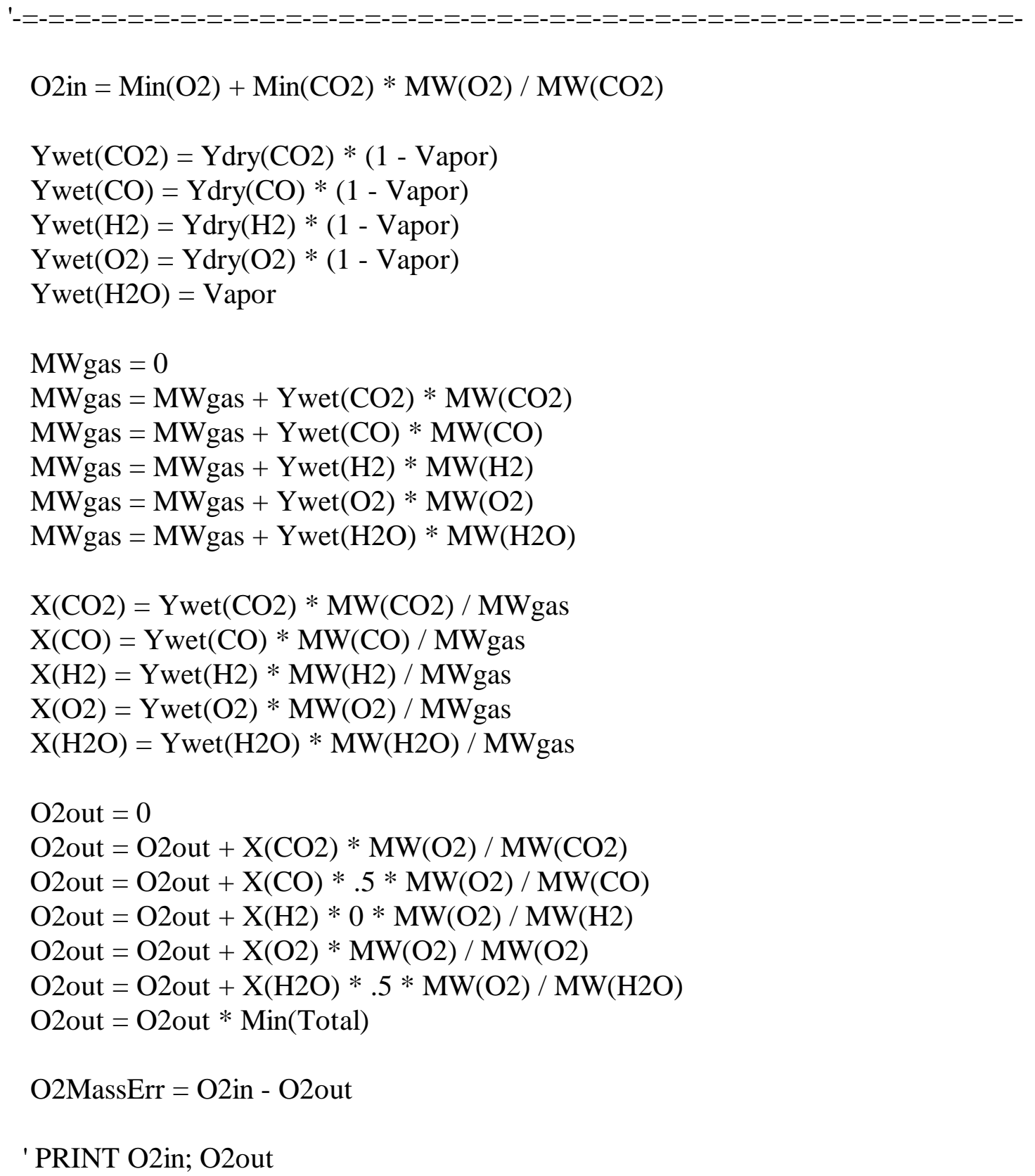

' PRINT O2in; O2out

END FUNCTION 
SUB SolveH2O

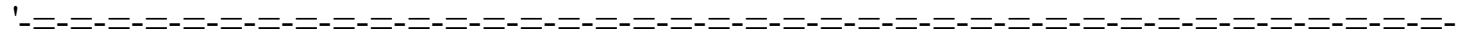

'use bisection to find volume fraction water that minimizes $\mathrm{O} 2$ mass balance

'error

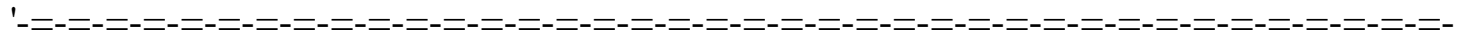

$\mathrm{Tol}=.001$

LowH2O $=0$

$\mathrm{HiH} 2 \mathrm{O}=1$

$\mathrm{HiErr}=\mathrm{O} 2 \mathrm{MassErr}(\mathrm{HiH} 2 \mathrm{O})$

LowErr $=$ O2MassErr $($ LowH2O)

IF HiErr * LowErr $>0$ THEN

BEEP: BEEP: BEEP: BEEP: BEEP

PRINT "There is no Solution!"

PRINT "LowErr="; LowErr

PRINT "HiErr="; HighErr

$\mathrm{MidH} 2 \mathrm{O}=0$

ELSE

DO WHILE $((\mathrm{HiH} 2 \mathrm{O}-\mathrm{LowH} 2 \mathrm{O})>\mathrm{Tol})$

$\mathrm{MidH} 2 \mathrm{O}=(\mathrm{HiH} 2 \mathrm{O}+\mathrm{LowH} 2 \mathrm{O}) / 2 !$

MidErr $=$ O2MassErr $($ MidH2O $)$

IF LowErr * MidErr $<=0$ THEN

$\mathrm{HiH} 2 \mathrm{O}=\mathrm{MidH} 2 \mathrm{O}$

HiErr $=$ MidErr

ELSE

LowH2O $=$ MidH2O

LowErr $=$ MidErr

END IF

LOOP

END IF

Ywet $(\mathrm{H} 2 \mathrm{O})=\mathrm{MidH} 2 \mathrm{O}$

Ywet $(\mathrm{CO} 2)=\mathrm{Ydry}(\mathrm{CO} 2) *(1-\mathrm{MidH} 2 \mathrm{O})$

Ywet(CO) $=\mathrm{Ydry}(\mathrm{CO}) *(1-\mathrm{MidH} 2 \mathrm{O})$

$\mathrm{Ywet}(\mathrm{H} 2)=\mathrm{Ydry}(\mathrm{H} 2) *(1-\mathrm{MidH} 2 \mathrm{O})$

$\mathrm{Ywet}(\mathrm{O} 2)=\mathrm{Ydry}(\mathrm{O} 2) *(1-\mathrm{MidH} 2 \mathrm{O})$

END SUB. 